\title{
Recent Update on the Molecular Mechanisms of Gonadal Steroids Action in Adipose Tissue
}

\author{
Agata Wawrzkiewicz-Jałowiecka ${ }^{1, *(1)}$, Anna Lalik ${ }^{2,3}$ (D) and Graça Soveral ${ }^{4}(\mathbb{D}$ \\ 1 Department of Physical Chemistry and Technology of Polymers, Silesian University of Technology, \\ 44-100 Gliwice, Poland \\ 2 Department of Systems Biology and Engineering, Silesian University of Technology, Akademicka 16, \\ 44-100 Gliwice, Poland; anna.lalik@polsl.pl \\ 3 Biotechnology Center, Silesian University of Technology, B. Krzywoustego 8, 44-100 Gliwice, Poland \\ 4 Faculty of Pharmacy, Research Institute for Medicines (iMed.ULisboa), Universidade de Lisboa, \\ 1649-003 Lisboa, Portugal; gsoveral@ff.ulisboa.pt \\ * Correspondence: agata.wawrzkiewicz-jalowiecka@polsl.pl; Tel.: +48-32-237-12-85
}

\section{Citation:}

Wawrzkiewicz-Jałowiecka, A.; Lalik, A.; Soveral, G. Recent Update on the Molecular Mechanisms of Gonadal Steroids Action in Adipose Tissue. Int J. Mol. Sci. 2021, 22, 5226. https:// dx.doi.org/10.3390/ijms22105226

Academic Editor: Agnieszka Kaczor

Received: 15 April 2021

Accepted: 11 May 2021

Published: 14 May 2021

Publisher's Note: MDPI stays neutral with regard to jurisdictional claims in published maps and institutional affiliations.

Copyright: (c) 2021 by the authors. Licensee MDPI, Basel, Switzerland. This article is an open access article distributed under the terms and conditions of the Creative Commons Attribution (CC BY) license (https:/ / creativecommons.org/licenses/by/ $4.0 /)$.

\begin{abstract}
The gonadal steroids, including androgens, estrogens and progestogens, are involved in the control of body fat distribution in humans. Nevertheless, not only the size and localization of the fat depots depend on the sex steroids levels, but they can also highly affect the functioning of adipose tissue. Namely, the gonadocorticoids can directly influence insulin signaling, lipid metabolism, fatty acid uptake and adipokine production. They may also alter energy balance and glucose homeostasis in adipocytes in an indirect way, e.g., by changing the expression level of aquaglyceroporins. This work presents the recent advances in understanding the molecular mechanism of how the gonadal steroids influence the functioning of adipose tissue leading to a set of detrimental metabolic consequences. Special attention is given here to highlighting the sexual dimorphism of adipocyte functioning in terms of health and disease. Particularly, we discuss the molecular background of metabolic disturbances occurring in consequence of hormonal imbalance which is characteristic of some common endocrinopathies such as the polycystic ovary syndrome. From this perspective, we highlight the potential drug targets and the active substances which can be used in personalized sex-specific management of metabolic diseases, in accord with the patient's hormonal status.
\end{abstract}

Keywords: sex hormones; adipose tissue; metabolic disorders; insulin sensitivity; lipid metabolism; adipokines; microRNA; microRNA-oriented therapy; polycystic ovary syndrome; aquaporins

\section{Introduction \\ 1.1. Adipose Tissue Function}

Adipose tissue plays an important physiological role as a central metabolic organ in the regulation of whole-body energy homeostasis in mammals and some non-mammalian animal species [1,2]. The white adipose tissue (WAT) functions as the main energy reservoir of the body, where the energy is stored in the form of triglycerides. In turn, the brown adipose tissue (BAT) accumulates lipids for cold-induced adaptive thermogenesis.

The adipose tissue is also recognized as a major multitasking endocrine organ due to its ability to produce and secrete hormones, cytokines and microRNAs, as well as a wide range of proteins of multiple functions including immune-related proteins, complement-related proteins or the proteins involved in lipid metabolism or transport $[3,4]$. As a consequence, the dysfunction of adipose tissue frequently leads to obesity and other metabolic abnormalities [5], as well as other health problems such as non-alcoholic fatty liver disease (NAFLD) [6-10]. Improper adipose tissue functioning affects even the relatively remote organs and tissues, leading to many detrimental health consequences. Adipose tissue 
impairment is a notable factor in cardiovascular diseases (mainly via inducing obesityrelated hypertension) [11,12], has deleterious effects on microvascular and macrovascular functions [13] and promotes thrombosis [14]. Adipocytes' malfunction affects secretion of a wide range of bioactive molecules: adipocytokines, microRNAs and inorganic compounds such as hydrogen sulfide $\left(\mathrm{H}_{2} \mathrm{~S}\right)$, which directly influence the functioning of the cardiovascular system [15-20]), evoke inflammatory illnesses (e.g., inflammatory bowel disease [21] and Crohn's disease [22]) or have other long-range consequences, for example osteoarthritis [23-25].

The adipose tissues are recognized as significant sites for transformation of sex steroid hormones and their action, as recently summarized in [26,27]. In turn, gonadal steroids are important factors in the determination of fat distribution and accumulation [28-32]. Moreover, sex steroid hormones clearly exert detrimental effects on adipocytes functioning, including lipolysis and lipogenesis, insulin sensitivity and its endocrine role (e.g., adipokine production and regulation of microRNAs expression) $[26,27,33]$, as briefly summarized in Figure 1.

The primal factor that controls the function and metabolism of adipocytes (as all other cell types) is the level of gene expression, which can be post-transcriptionally regulated by microRNA. In turn, the expression of microRNAs is controlled by biochemical agents, including gonadal steroids and adipokines [34-38].

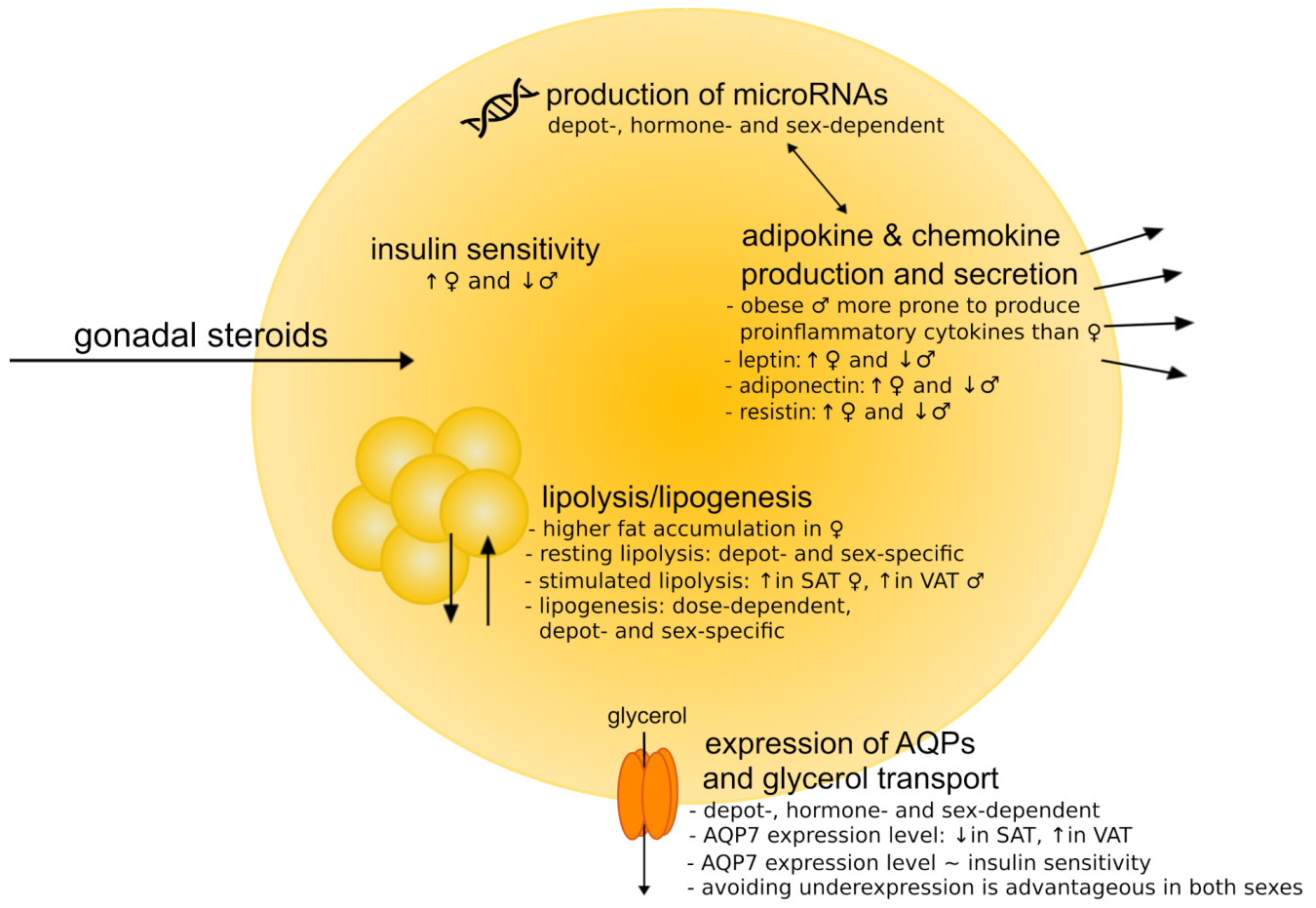

Figure 1. Schematic representation of the most important processes of adipocyte functioning affected by gonadal steroids and the main sex-differences. Sex hormones influence the expression levels of microRNAs, lipolysis and lipogenesis, insulin sensitivity and endocrine function of adipocytes (e.g., adipokine production). One of the most prone connecting links between sex-hormonal imbalance and the disruption of adipose tissue functions is the expression level of aquaporins (AQPs) (in particular, aquaglyceroporins) and, consequently, the effectiveness of the glycerol efflux from adipocyte.

\subsection{Gonadal Steroids}

The group of gonadocorticoids, commonly known as sex hormones or sex steroids, is constituted by progestogens, androgens and estrogens. The first representatives of the sex hormones are progestogens, with progesterone as the major and most physiologically important in the human body. Progesterone is produced from cholesterol through a series of reactions and intermediates (Figure 2). In the initial step, cholesterol is converted into preg- 
nenolone, which serves as the precursor to the progesterone and $17 \alpha$-hydroxyprogesterone. Along with another steroid, $17 \alpha$-hydroxypregnenolone, these progestogens are the precursors of all other endogenous steroids [39,40] (Figure 2). Progesterone is mainly recognized as the hormone required for maintaining pregnancy.

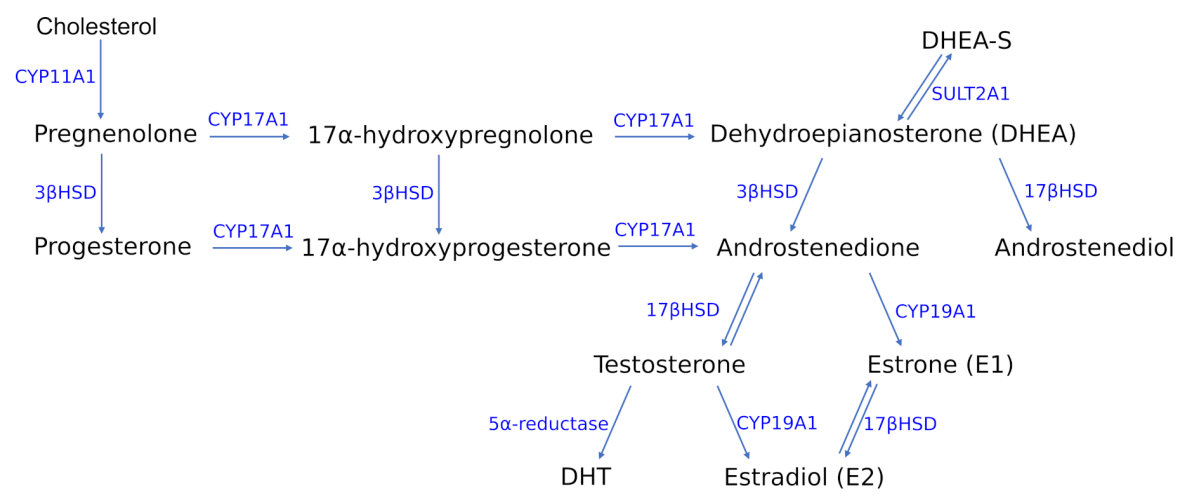

Figure 2. Adipose tissue is an important side for sex hormone interconversions. This figure summarizes the most prominent reactions of this kind. All sex hormones can be synthesized de novo from cholesterol in presence of active steroid hormones. However, more frequently in adipose tissue, the hormones are taken up from plasma and further transformed into other ones. The direction and efficiency within the steroid biosynthetic pathways in adipose tissue depends on the relative expression and activity of steroidogenic enzymes, which are gender-, age- and depot-specific. Abbreviations: CYP11A1, cholesterol side-chain cleavage enzyme; CYP17A1, steroid $17 \alpha$-monooxygenase; $3 \beta$-HSD, $3 \beta$-hydroxysteroid dehydrogenase; $17 \beta$-HSD, 17 $\beta$-hydroxysteroid dehydrogenase; SULT2A1, dehydroepiandrosterone sulfotransferase; DHT, dihydrotestosterone.

Among the most potent androgens in human organism are testosterone (T), dihydrotestosterone (DHT), androstenedione, dehydroepiandrosterone (DHEA) and dehydroepiandrosterone sulfate (DHEA-S) [41]. Within the estrogenes the most prominent physiological role in the human body is played by the $17 \beta$ estradiol (E2), followed by estrone (E1) and estriol (E3) [42]. E2 is produced from androgens through the pathway involving formation of androstenedione, which is subsequently converted by aromatase (CYP19A1) into estrone and then transformed into estradiol (Figure 2). It can also be synthesized through the second pathway that is based on the interconversion of steroids from androstenedione into testosterone in the presence of $17 \beta$-hydroxysteroid dehydrogenase (17 $\beta$-HSD), which is then converted into estradiol [40] (Figure 2).

\subsection{Perspectives}

In this review, the effects of androgens, progestogens and estrogens on adipose tissue functioning are examined considering the recent advances addressing the molecular aspects of that phenomenon. The direct biochemical mechanisms of gonadal steroids action on the adipocyte functioning are here discussed as well as the most notable possibilities of their indirect modulation. In addition, considering the involvement of aquaporins (AQPs), particularly aquaglyceroporins, in adipocyte biology [43] (Figure 1), we discuss the indirect effects of gonadal steroids on energy metabolism via modulation of aquaglyceroporins. It may give a mechanistic substantiation of the observed impairment of adipocyte functioning in terms of sex-hormonal imbalance that has not been broadly discussed in the context of gonadal steroids action in adipose tissue, hitherto. In this work, the hormonal imbalance pathogenic impact is also analyzed taking into consideration the possible post-transcriptional regulation of gene expression via microRNA.

The identification of at-risk populations taking into account the gender differences in obesity and metabolic dysfunctions, e.g., the worldwide female predominance in obesity or the male prevalence in the total cases of type 2 diabetes (T2D) [44], will foster new therapeutic procedures for diseases leading to sex steroids' imbalance, which are often gathered 
by metabolic disturbances, including endocrinopathies (e.g., polycystic ovary syndrome (PCOS) $[45,46]$ and hypogonadism in men $[47,48]$ ) or autosomal recessive disorders (e.g., congenital adrenal hyperplasia $[49,50])$. Other health conditions, such as the case of the overweight men with visceral adipose tissue accumulation who are at relatively high risk for low androgen levels and developing T2D [51-53] or the decreased estrogen and progesterone levels accompanied by increase in overall adiposity due to visceral adipose tissue accumulation in menopausal women, clearly underscore the importance of sex steroid hormones in proper functioning of adipose tissue [54]. Moreover, this work highlights the sexual dimorphism in the regulation of energetic, glucose and lipid homeostasis, shedding new light on the need of development personalized sex-specific approaches in therapies against metabolic diseases.

The design of efficient therapies to alleviate metabolic abnormalities taking into account the sex dimorphism programmed by the hormonal disparities in men and women should be preceded by unraveling the mechanism of their pathogenesis at the molecular level in a step-by-step manner. From such a perspective, we summarize here the most promising scientific developments in the search of novel drug targets, as well as active substances, which can act on the initial causes of the metabolic disorders at a molecular level. The potential sex-specificity of their therapeutic efficiency is also discussed.

\section{Effects of Gonadal Steroids on Body Fat Distribution in Humans and Adipocyte Morphology}

One of the most evident impact of the gonadal steroids on the body refers to the adipose tissue distribution [31]. There are significant sex differences in body composition [31,44,55] (Figure 3), where women have a higher percentage body fat than men and accumulate fat mainly in the form of subcutaneous adipose tissue (SAT), creating a "gynecoid" type of distribution (in gluteal-femoral depots) [56]. In turn, men tend to accumulate their fat as visceral adipose tissue (VAT) around the abdominal organs [57]. The abdominal VAT deposition correlates with an increased susceptibility for cardiometabolic complications [58,59]. On the contrary, the gluteal-femoral adipose tissue distribution plays a protective role against the adverse health effects of metabolic diseases [60,61].

Sex-specific fat distribution is influenced by several factors, including genetical factors as well as hormonal and diet status $[31,62,63]$. The most prominent effect is, however, exerted by the hormonal bias, which is clearly visible by comparison of premenopausal and postmenopausal women. The reduction in the levels of estrogen after menopause results in increased fat storage in abdominal depots [64-66].

The effects of sex steroid hormones on adipocyte differentiation and morphology, and consequently on fat deposition, are mediated by the presence of their receptors including $\alpha$-ER and $\beta$-ER estrogen receptors, $\alpha$-PR and $\beta$-PR (progesterone receptors) and the $\alpha$ $\mathrm{AR}$ and $\beta$-AR adrenergic receptors $[28,67,68]$. These receptors are expressed in sex- and depot-dependent manner in preadipocytes and adipocytes within the human body [69].

As suggested by the analysis of a mouse model, the impairment in estrogen signaling evoked by the knockout of ER $\alpha$ results in obesity, insulin resistance and diabetes regardless of gender [70-73]. According to the literature [28], the AR gene expression is affected by the gonadal steroids in both preadipocytes and adipocytes, which is important in shaping the sex-related differences in adipose tissue regional distribution. It turns out that $\alpha_{2 A}$-AR is the prevailing AR subtype expressed in preadipocytes, whereas, in mature adipocytes, the $\beta_{3}$-AR is dominant [28].

Although the sex hormone receptors are expressed in preadipocytes as well as in adipocytes of VAT and SAT depots in human body, some sex-dependent differences of expression level occur. The subcutaneous adipose tissue has higher concentrations of ERs and PRs compared to ARs in females, and E2 downregulates AR expression in SAT [70,74,75]. In contrast, visceral adipose tissue has a higher concentration of ARs [74,76]. These differences in expression level of sex steroid receptors may highly influence the differentiation and morphology of adipocytes [27]. 


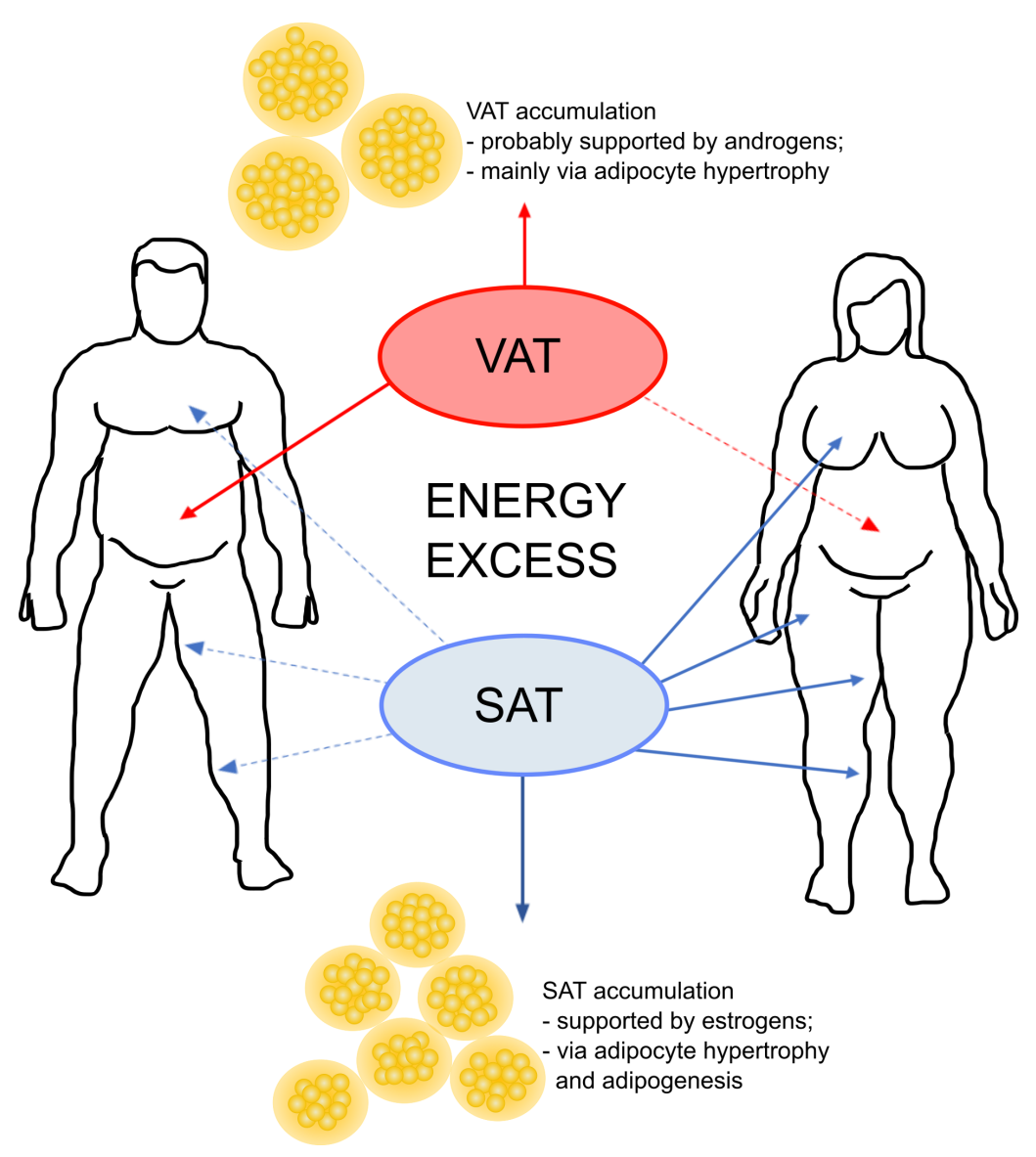

Figure 3. Schematic representation of sex-dependent differences in the fat deposition patterns. The visceral adipose tissue (VAT) is located around the abdominal organs and is the main type of fat depots in men. On the contrary, women distribute fat mostly in the form of subcutaneous fat. In general, increased visceral mass predominantly results from adipocyte hypertrophy, whereas subcutaneous fat (SAT) grows through both hypertrophy and hyperplasia (with prevailing hyperplastic mechanism) $[77,78]$. Considering sex-dependent differences in growth of gonadal fat depots, it is observed that, in response to energy excess, male gonadal depot grows mainly through hypertrophy, while female gonadal depots expand both hypertrophy and hyperplasia [79].

In terms of energy excess, the adipose tissue expands by increasing the number (hyperplasia) and/or size (hypertrophy) of adipocytes [80,81]. Hyperplastic growth is considered to be healthier in opposition to the hypertrophic expansion, which leads to adipocyte death, lipotoxicity, insulin resistance and high inflammation [82-85]. In response to energy excess, the typical male VAT depots expand mainly through hypertrophy [82], while female gonadal and subcutaneous depots grow through both hypertrophy and hyperplasia. This has reasonable grounds considering the hormonal bias. Namely, proliferation of preadipocytes is upregulated by estrogens with greater effects in preadipocytes isolated from SAT vs. VAT and females vs. males [79]. In turn, androgens hamper adipogenesis in in vitro and in vivo trials and the effects are greater in preadipocytes from VAT vs. SAT [79,86-90].

Considering the role of progesterone in body fat accumulation, it was proposed that this sex hormone might be responsible for gynoid fat distribution in premenopausal women in an indirect mechanism. It may attenuate the effects of cortisol in WAT via glucocorticoid receptor, therefore, it hampers cortisol-related central fat accumulation [91]. The analysis of progesterone action on murine and human preadipocytes differentiation gave inconsistent results. It was found that progesterone stimulated adipogenesis in the 3T3-L1 adipose cell line [92], however it was without effect on cultured human preadipocytes [93].

An important contributor to sex bias in adipose tissue distribution and adipocyte size may be the rate of direct fatty acid uptake by tissues. Direct fatty acid uptake is 
higher in the abdominal depot in men and in the gluteal-femoral depot in women [94]. Another potential factor that contributes to sex differences in adipose tissue expansion is nourishment [27]. In a mouse model, the number of adipocyte precursor cells in gonadal or subcutaneous fat is highly dependent on $\operatorname{diet}$ [95].

\section{The Direct Influence of Sex Steroids on Adipocyte Functionality}

This section summarizes the molecular mechanisms of the direct effects of gonadocorticoids on versatile aspects of adipose tissue functioning. Sex hormones frequently act on adipocytes in a sex-dimorphic, dose-dependent and depot-specific manner.

\subsection{Lipolysis and Lipogenesis}

The processes of lipolysis and lipogenesis within adipose tissue control the energy release and energy storage in the body. During lipolysis triglycerides are hydrolyzed into glycerol and free fatty acids (FFA). There are significant differences between men and women in basal lipolysis rates in terms of resting energy expenditure which occur in a depot-specific manner [75]. There are also sex-differences in stimulated lipolysis, being greater in women's abdominal SAT and in men's VAT [31,75].

Consistent with an inhibitory effect on adipogenesis, androgens have been shown to increase lipolysis, and consequently support adipocyte hypertrophy $[68,96]$. In a rat model, isoproterenol and noradrenaline-stimulated lipolysis were increased by T (but not DHT) in male preadipocytes [97]. An additional stimulating effect is exerted by DHEA via upregulation of adipose triglyceride lipase (ATGL) and hormone-sensitive lipase (HSL) mRNA [98]. In humans, lipolysis is enhanced by androgens in a dose-dependent and depot-specific manner. The in vitro studies have found that testosterone and dehydroepiandrosterone stimulate norepinephrine-stimulated lipolysis and depresses lipoprotein lipase activity (LPL) in adipose cells [99].

The results presented in $[100,101]$ indicate that castrated rodents display reduced basal and catecholamine-stimulated lipolysis, but introduction of the testosterone supplementation allowed to fully normalize their lipolytic activity. Another study showed that androgens can downregulate hormone-sensitive lipase (HSL) and $\beta_{2}$-AR expression, and consequently reduce catecholamine-stimulated lipolysis, particularly in subcutaneous adipocytes [102]. The investigation of the effects of dihydrotestosterone on differentiation and proliferation of human mesenchymal stem cells and preadipocytes by Gupta et al. [87] showed that DHT decreased differentiation of fat cell precursors, increased lipolysis and reduced lipid accumulation. The androgenic effects on lipolysis are believed to be mediated by the AR since flutamide (being the AR antagonist) significantly abolished these effects [103]. However, other additional mediators are also considered, e.g., hormonesensitive lipase and adenylate cyclase [97,100,101,104].

Analyzing the effects of estrogens on lipid storing and mobilization, it is reported that E2 allows to suppress lipogenesis and lipogenic gene expression and promote both basal and catecholamine-induced lipolysis [26]. As mentioned above, lipolysis is controlled to a large degree by hormone receptors. The effects of estradiol on lipogenesis are mediated by $\alpha$-ER receptor activation, which reduces LPL activity (fundamental for fat uptake into the adipocytes) and increases $\beta$-AR and $\alpha_{2 A}$-adrenergic receptors in SAT [105]. The examination of women with low estrogen levels also indicated reduced LPL activity when the hypogonadal women obtained estrogen replacement therapy [106]. In contrast, estradiol exerts no effects on $\alpha_{2 A}$-adrenergic receptors mRNA expression in adipocytes from the visceral fat depots [105]. Thus, the effects of estrogens on lipolysis are depot-specific, facilitating the typical female subcutaneous fat accumulation.

Estradiol also exerts additional effects on lipid metabolism. Namely, the E2 downregulates adipogenic peroxisome proliferator-activated receptor $\gamma(\operatorname{PPAR} \gamma)$ expression and the key lipolytic genes including the ones encoding stearoyl-CoA desaturase 1 (SCD1), fatty acid synthase (FAS) and acetyl-CoA carboxylase 1 (ACC1) [68,107]. E2 also enables increasing muscle oxidative capacity $[54,108]$ through the regulation of acyl-CoA oxi- 
dase and uncoupling proteins (UCP2-UCP3), which enhances fatty acid uptake without lipid accumulation.

The effects of progestogens, especially progesterone, on lipid metabolism are not as broadly described as the influence of other corticosteroids. There are contradictory reports of the role of progesterone in lipogenesis and lipolysis, with the dominating view that this hormone supports lipogenesis and hampers lipolysis. As indicated in [109], in diabetic rats, progesterone stimulates lipogenesis in adipose tissue without any increase in food intake or serum insulin concentrations. Moreover, the results presented in the work of Stelmańska et al. [110] indicate that the elevated blood progesterone concentration is associated with significant increase in expression of lipogenic enzyme genes (Srebf1 and S14 genes) in inguinal WAT of female rats. Another rodent study demonstrated that progesterone acts in a sexually-dimorphic way in rats [111]. In female rats, progesterone induced downregulation of hormone sensitive lipase and upregulation of G0/G1 switch 2 (G0s2) genes expression in inguinal white adipose tissue, which was reflected by lowered rate of stimulated lipolysis. In turn, in male WAT, progesterone has no effect on the expression of aforementioned genes. The last inference is in agreement with in vivo studies [112,113] that indicated that progesterone has no influence on lipid metabolism in male rats' adipose tissue. The former studies indicated that progesterone inhibits lipogenesis [114] and enhances lipolysis [115], whereas another study indicated that progesterone stimulates lipogenesis [116].

\subsection{Insulin Sensitivity}

Men are less sensitive to insulin than BMI- and age-matched women [26,117-119]. Obesity is one of the main risk factors for T2D. Although obesity is more frequently diagnosed in women than men, T2D occurs with increased prevalence in men [44]. Considering the molecular effects of gonadal steroids on insulin sensitivity, one has to realize that glucose-insulin homeostasis is systemically regulated in both sexes through hormone receptors $[26,70]$.

The regulatory role of $\alpha$-ER is mediated by modulation of the tyrosine phosphorylation of insulin receptor substrate 1 (IRS-1) protein [120]. Estradiol is able to activate adenosine monophosphate-activated protein kinase through ER, and consequently enhance the activity of protein kinase $\mathrm{B}$ (AKT) via $5^{\prime}$ AMP-activated protein kinase (AMPK), according to the in vitro studies presented in [121]. The role of androgens in glucose homeostasis is highly dimorphic in men and women, which is evident by the liability of hyperandrogenemic women (e.g., in the case of PCOS) and hypoandrogenemic males (suffering hypogonadism) to insulin resistance and obesity [122,123]. Administration of testosterone to differentiated, subcutaneous preadipocytes from lean women causes insulin resistance via insulin-stimulated phosphorylation of protein kinase $\mathrm{C} \zeta$ (PKC $\zeta$ ), which initiates the translocation of glucose into the cell via glucose transporter type 4 (GLUT4) [26,124]. In turn, in men, the insulin sensitivity can be modulated by $5 \alpha$-reductase (an enzyme involved in interconversion of T to DHT (Figure 2)) $[125,126]$.

The studies on a mouse model of PCOS indicated that the low-dose DHT causes lowering of the components of insulin signaling (e.g., GLUTs) in energy storage tissues but a simultaneous increase in the levels of insulin signaling components in reproductive tissues [127]. Another androgen, DHEA, is reported to increase glucose-stimulated insulin secretion in animal models $[26,128,129]$. Nevertheless, the data obtained from human studies significantly vary [129]. The general opinion states, however, that DHEA should evoke insulin sensitization and counteract obesity through downregulation of $11 \beta$-hydroxysteroid dehydrogenase type 1 (11 $\beta$-HSD1). Thus, DHEA might be considered as a promising target for the treatment of obesity and diabetes [130-132].

\subsection{Endocrine Function of Adipocytes}

In recent years, metabolic diseases including obesity, metabolic syndrome and T2D have become even more common. They result in the excess adiposity, which sustains a state of chronic low-grade inflammation characterized by infiltration of immune cells (mainly 
macrophages) into adipose tissue [133]. The infiltrated immune cells are, in turn, able to release inflammatory cytokines and chemokines [134]. Moreover, the presence of pro-inflammatory cytokines impairs insulin signaling, further leading to insulin resistance [134-136], among others. It can also result in endothelial dysfunction and subsequent atherosclerosis [27]. VAT, which is the predominant type of excess adipose tissue in men, has a greater number of adipose tissue resident macrophages in comparison with SAT depots, which is the predominant fat depot in women. Thus, obese men are more prone to produce pro-inflammatory cytokines than BMI-matched women, and, further, these sex-differences are also preserved in the relative number of insulin resistance cases and endothelial dysfunction morbidity. Nevertheless, the presence and functional impairment of abdominal fat are significant risk factors for sexual dysfunction in both genders $[137,138]$.

\subsubsection{Leptin Production}

Leptin is an endocrine hormone able to regulate immunity and energy homeostasis (by exerting an anorectic effect related to its action in the hypothalamus and, further, by enhancing lipolysis). Gonadal steroid hormones are able to determine the sexual dimorphism in serum leptin level, which is higher in women than men regardless of age [79]. The literature suggests that the estradiol increases leptin secretion from omental adipocytes in women by controlling synthesis of transcripts encoding leptin and the expression of leptin-specific receptors [79,139], but the E2 exerts no effects on men adipocytes [140]. Additionally, leptin concentrations in postmenopausal women are lower than in premenopausal women [54]. The positive influence of estrogen on leptin level in females was also confirmed in an animal model [141].

An opposite effect is exerted by androgens. Both testosterone and dihydrotestosterone decrease leptin gene expression and secretion from human adipocytes [142]. As can be inferred from the in vitro studies on 3T3-L1 murine adipocytes, DHT probably reduces the level of secreted leptin by decreasing its transcript abundance [139].

\subsubsection{Adiponectin Production}

One of the crucial anti-inflammatory adipokines is adiponectin, which improves insulin sensitivity by suppressing hepatic glucose production and enhancing fatty acid oxidation in the liver and skeletal muscles. The plasma adiponectin concentrations are inversely correlated with the size of adipose tissue reservoir [143]. There is an evident sexual dimorphism in circulating adiponectin levels, i.e., men have lower adiponectin levels than women when matching BMI and age groups are compared [144]. This discrepancy between sexes is related to androgen levels, confirmed in cell culture models as well as in an animal model where castration increases adiponectin level that additionally could be attenuated by testosterone supplementation [144]. In line with these observations, men with hypogonadism have significantly higher total serum levels of adiponectin in comparison to healthy controls, which lowers along with the introduction of testosterone replacement therapy $[79,145]$. In turn, women suffering from PCOS have relatively low adiponectin levels $[146,147]$ which makes them prone to insulin resistance.

\subsubsection{Resistin Production}

Resistin is a hormone produced by adipocytes and contributes to obesity and T2D. In a mouse model this peptide hormone caused insulin resistance when it was exogenously supplied [148]. In the same study, administration of anti-resistin antibodies improved blood sugar and insulin action in mice with diet-induced obesity. Human studies showed that resistin is relatively high in adult women, but does not differ in boys and girls throughout the stages of puberty [149].

Some observations were made during the analysis of human endocrinopathies. Munir et al. [150] showed that serum resistin concentration was positively correlated with BMI and testosterone level in PCOS women, but not in controls. In turn, the mean serum resistin concentration was increased (of $40 \%$ ) in women with PCOS. The results presented 
by Seow et al. $[151,152]$ show that the mRNA resistin level in adipocytes was higher in PCOS women than in controls [147], although other reports suggest no PCOS-related effects on resistin concentration or expression $[153,154]$. In the case of hypogonadal men, introduction of testosterone replacement therapy does not affect circulating resistin concentrations in serum [155].

\subsubsection{Production of Pro-Inflammatory Adipocytokines}

There are some sex-related differences in human immunity, which partially stem from the influences of different gonadal steroids on leukocyte biology but also are inclined by genes on sex chromosomes [156]. The levels of gonadal corticoids may deeply influence the adipose tissue immune cell populations via regulation of their proliferation, differentiation and apoptosis [157-160]. Further, estrogens and androgens regulate the secretion of bioactive molecules by immune cells, which are related to inflammation, endothelial functionality and insulin sensitivity in adipocytes $[26,27,79,158,160,161]$. The effects of estrogens and progestogens on cytokine and immunoglobulin production in different immune cell types (e.g., T lymphocytes, monocytes, B lymphocytes, granulocytes, natural killer cells and dendritic cells) were summarized by Oertelt-Prigione [160], and an analogous detailed analysis of the androgen effects on immune cells is provided in $[157,159,161]$.

As mentioned above, sexual dimorphism in immunity manifest itself in the disparate abilities to produce inflammatory biomarkers in men and women, which include C-reactive protein (CRP), tumor necrosis factor (TNF $\alpha$ ) and some interleukins (IL-1, IL-6 and IL-12). In addition, there are notable differences in responsibility and activity of other molecules and molecular complexes regulating the immune response to infection such as the nuclear factor kappa-light-chain-enhancer of activated B cells (NF- $\kappa$ B) $[137,156]$. The in vitro studies from Ghisletti et al. [162] showed that the estradiol administration blocks the inflammatory response. According to the study on ovariectomized female mice, administration of estrogens significantly lowers the mRNA levels of IL-6, TNF $\alpha$ and CD68. In addition, estrogen prevented female mice from developing liver steatosis and from becoming resistant to insulin $[54,163]$. Nevertheless, chronic estradiol administration to ovariectomized mice enhances pro-inflammatory cytokine production of IL- $1 \beta$, IL-6 and TNF $\alpha[164,165]$. Considering the mechanism of the anti-inflammatory effects of estradiol, one of the component processes is that E2 prevents transcription of genes encoding pro-inflammatory mediators (inhibiting intracellular transport of p65, which is a member of NF- $k \mathrm{~B}$ family, to the nucleus) $[162,166]$. This activity is selectively mediated by $\alpha$-ER receptor $[156,162,167]$.

Most innate immune inflammatory cytokines (IL-6, IL-8, TNF $\alpha$ ), are inhibited in women by periovulatory dosages of estrogen. The studies on postmenopausal women show that low levels of estradiol can augment inflammatory mediators, which could explain the pro-inflammatory states in this group of women [168].

Considering the role of androgen in the immune system, androgens administration in hypogonadal men may reduce systemic inflammation. Testosterone is reported to have immunosuppressive and anti-inflammatory functions. In fact, this hormone was found to lower IL- 6 and TNF- $\alpha$ levels through inhibition of the NF- $\kappa$ B pro-inflammatory pathway, analogously to estrogen [169]. Consequently, testosterone replacement in hypogonadal men can give rise to increased serum levels of IL-10 and reduced TNF $\alpha$ and IL-1 $\beta$ [170].

\subsection{Sex-Related Discrepancies in Immunological Responses}

The immunological responses mediated by adipose tissue functioning present some sex-related discrepancies. Cytokine secretion by the peripheral blood mononuclear cells (PBMCs) occurs in a gender-dependent manner, which coincides with elevated estrogen levels [171]. The PBMCs from men produce more pro-inflammatory TNF $\alpha$ and less protective IL-10 than PBMCs from women, which may explain a better outcome of diseases such as sepsis in females.

Susceptibility to viral infections as well as their severity are higher in men than in women, which was broadly discussed due to the current COVID-19 crisis [156,172-175]. 
This variability could be partly explained by the sex-differences in the activity of the TollLike Receptors (TLR) which are involved in the virus recognition. Higher male liability to viral infection can be in part attributable to higher cytokine secretion by the PBMCs leading to enhanced TLR9 activation and increased IL-10 production, which is positively correlated with androgen concentrations [172].

The results from Channappanavar et al. [173] based on a mouse model of SARS$\mathrm{CoV}$ infection matched the appropriate epidemiological data from SARS outbreaks and indicated a notable male bias in disease susceptibility. It also demonstrated a protective effect for estrogen receptor signaling in mice infected with SARS-CoV (ovariectomy or treating female mice with an estrogen receptor antagonist increased mortality). The recent data describing the profiles of SARS-Cov-2-infected patients show that the levels of several important pro-inflammatory innate immunity chemokines and cytokines (e.g., IL-8 and IL-18) are higher in male patients. However, more robust $\mathrm{T}$ cell activation is exhibited by women than men. A poor T cell response is negatively correlated with patients' age and is related to worse disease outcome in male, but not female, patients [174]. From this perspective, it is possible that estrogen plays a similarly protective role against SARSCoV-2 as in the case of SARS-CoV. Analogously, relatively high testosterone exerts an anti-inflammatory effect in men and frequently protects younger men against adverse outcomes of SARS-CoV-2 infection.

\section{Modulation of Aquaporins by Sex Steroids as an Indirect Mechanism of Adipose Tissue Regulation}

The studies on pathogenesis of metabolic diseases requires detailed analysis of the molecular mechanisms of the gonadal steroids on adipose tissue. We are convinced that in this case not only the direct biochemical pathways already broadly discussed in literature should be analyzed. As in every scientific discussion, one should also consider a global view of the research problem and point out its critical components which shape the main cause and effect relationships. One of the connecting links between sex-hormonal imbalance and the disruption of adipose tissue function is the activity of aquaporins.

As a fundamental property of life, the flow of water and small solutes across cell membranes is crucial for the correct course of physiological processes. Aquaporins (AQPs) are transmembrane proteins responsible for bidirectional transport of water and small solutes (including ammonia, $\mathrm{CO}_{2}$, glycerol and urea) across biological membranes in response to osmotic or solutes' gradients [176]. Thus far, thirteen AQP isoforms have been identified (AQP0-AQP12) in human [177]. They can be divided into two main classes based on their permeability characteristics [178]. The "classical" ones are mainly selective to water (AQP0, AQP1, AQP2, AQP4, AQP5, AQP6 and AQP8). The other group is formed by aquaglyceroporins (AQP3, AQP7, AQP9 and AQP10), being able to transport small non-charged solutes such as glycerol and urea. The structure and function of the remaining AQP11 and AQP12, sometimes called "unorthodox" or "superaquaporins", are relatively poorly understood. Moreover, among aquaporins, the group of ammoniaporins (AQP3, AQP6, AQP7, AQP8 and AQP9) is recognized for their ammonia transport ability $[179,180]$ while peroxiporins (AQP3, AQP5, AQP8, AQP9 and AQP11) guarantee the efficient transport of $\mathrm{H}_{2} \mathrm{O}_{2}$ across the plasma and organelle membranes [181-186].

The members of the aquaglyceroporin subfamily exert a high impact in the crucial aspects of adipose tissue functioning, mentioned in the former sections of this work. Namely, AQP7 is considered as the main glycerol channel in adipose tissue, facilitating the release of lipolytic glycerol from adipocytes in response to the energy demand [43,187-190]. AQP7 deficiency results in reduced membrane glycerol permeability which leads to increased triglyceride accumulation inside adipocytes and adipocyte hypertrophy contributing to the onset of obesity [188,191-193]. AQP7 is not the sole aquaglyceroporin in adipose tissue [43]. Recently, AQP3, AQP9, AQP10 and AQP11 were additionally identified in human adipocytes and suggested as additional glycerol pathways in these cells, unveiling their role as key players in lipid balance and energy homeostasis [194]. However, AQPs are differentially expressed in the two types of fat depot. Whereas visceral fat show increased AQP3 and AQP7 levels 
which can be correlated with increased lipolysis and glycerol release, in subcutaneous fat, AQP7 expression is lower, favoring fat accumulation and adipocyte hypertrophy $[43,187]$. In addition, gender differences in glycerol metabolism have also been reported in healthy and obese humans, with women showing higher fasting circulating glycerol levels and higher AQP7 expression than men in both subcutaneous and visceral adipose tissue probably due to hormonal regulation of adipose and liver aquaglyceroporins $[195,196]$. The sexual dimorphism in fat distribution and the gender-specific AQP7 levels may contribute to the lower prevalence of insulin resistance and metabolic disorders found in premenopausal women compared to men [196].

Aquaglyceroporins involvement in adipose tissue dysfunction and lipotoxicity in liver and muscle highlights their potential as therapeutic targets for the metabolic syndrome [197]. The literature reports indicate a close relationship between AQP7 and insulin sensitivity $[188,198]$. AQP7 is downregulated in terms of insulin resistance according to the in vitro studies on mice adipocytes where insulin resistance was induced by dexamethasone or TNF $\alpha$ [198]. Furthermore, overexpression of AQP7 contributes to improve sensitivity to insulin [198]. According to the results obtained in mice [199], the suppression of AQP7 expression by insulin proceeds through an insulin negative response element (IRE) located on the promoter region of the Aqp7 gene and is mediated by the phosphatidylinositol 3-kinase (PI3K) pathway. The human studies showed that the AQP7 gene was also negatively regulated by insulin via an insulin response element [200]. Moreover, the gene encoding AQP7 is localized in a chromosomal region (9 p13.3-p21.1) with reported linkage to the metabolic syndrome and to T2D [201,202].

It is also worth mentioning that peroxiporins are especially important in functioning of the immune system [203]. Due to their ability to facilitate hydrogen peroxide fluxes across biological membranes, they are tightly involved in redox balance and modulation of oxidative stress [186] and were reported to regulate immunological processes including inflammasome priming and activation [204].

Moreover, the water transport via aquaporins in immune cells enables them for shape and volume changes as well as maintaining an appropriate osmotic gradient across cell membrane, which are critical factors in cell-to-cell communication (via chemokines) and induction of changes in shape for migration, phagocytosis or antigen uptake [203]. Thus, aquaporins provide also a direct hydromechanical support for immune cells which is essential for their proper functioning.

Considering the merit of this work, it is worth emphasizing that aquaporins play an important role in female and male reproductive systems [205-207], and the alteration of their expression can be frequently linked with infertility [206,208], among others. Hormonal alterations are a known factor leading to reduced reproductive health and might frequently be associated with altered AQPs expression and function not only at a gonadal level, but such effects can occur systemically.

The regulation of AQPs level by estrogen is relatively well documented in literature. This steroid hormone can regulate AQP expression in the female reproductive system (uterus, vagina, ovary, cervix and placenta) $[209,210]$, as well as in the men reproductive system (efferent ducts, epididymis and Sertoli cells) [206,211-214]. Rodent and human studies suggest that there is a positive correlation between aquaporin expression levels (particularly AQP1-APQ3) and the $17 \beta$-estradiol concentration in gonads and in serum in females [207]. The opposite relation between E2 and AQPs is found in men, where the levels of AQP1, AQP3 and AQP9 were broadly studied [206]. In that case, however, the downregulation of AQPs expression (AQP3 and AQP9) by E2 in men is thought to be partly restored by testosterone administration $[213,214]$.

There are sparse data describing the direct effects of testosterone on the abundance of aquaporins within the body. To shortly sum up, testosterone is reported to increase the AQP1, AQP5 and AQP7 expression in ovariectomized rats, which may explain the observation that the T hormone is linked to a decrease in uterine fluid volume [215]. In male rats, APQ9 abundance in epididymal epithelium is modulated by testosterone [216]. In 
addition, the rate of ductus deferens fluid secretion under testosterone influence is mediated via the upregulation of AQP1, AQP2 and AQP9 [217]. In turn, decreased prostatic and seminal vesicle secretions during the ongoing deprivation in androgen level is related to the decrease in AQP0, AQP1, AQP4, AQP5, AQP6 and AQP8 in prostatic tissue and seminal vesicles [218].

Additionally, higher blood pressure is recorded in males as compared to females. In turn, within women, there are also changes in tendencies to hypertension between the premenopausal and postmenopausal ones, where the later are more prone to high blood pressure. There is a hypothesis that these phenomena can be explained by the testosterone-induced increase in blood pressure mediated by the changes in aquaporin expression in kidneys. The studies on a rat model confirm that hypothesis [219]. Testosterone administration causes exaggerated AQPs expression in kidneys which results in $\mathrm{H}_{2} \mathrm{O}$ retention and further gives rise to changes in the blood pressure [219]. Testosterone is also thought to influence brain edema via altering the osmotic fragility of astrocytes through AQP4 regulation [220].

Progesterone may also influence the aquaporins expression level, and this kind of influence plays a critical role during pregnancy. According to the results obtained in [221], progesterone upregulates the expression of AQP1 in the rat placenta and enhances abundance of AQP1 and AQP5 in the uterine tissue [222]. Progesterone exerts a similar effect in women to estrogen [207]. There is a positive correlation between progesterone level in serum and the AQP2 expression levels in endometrium [223]. Interestingly, an AQP3 functional genetic polymorphism was found associated with hypertension in women only after pregnancy [224].

What are the additional potential mechanisms of how the changes in steroid hormone levels may affect the AQPs expression within the organism (and particularly in adipose tissue)? A key to answer that question is the fact that the AQP7 expression in fat cells is sensitive to glucocorticoids, fasting-refeeding, insulin, $\mathrm{TNF} \alpha$, adrenoceptor agonists and peroxisome proliferator-activated receptor (PPAR) stimulation [192,199,225]. As summarized in the previous part of this work, most of the mentioned factors are deeply affected by the level of gonadal steroids. Thus, hormonal imbalance exert an indirect effect on aquaporins. This effect is, however, an important factor contributing to the observed metabolic complications in patients suffering abnormal sex hormone levels. For example, the excess amount of androgens in women (e.g., in PCOS) leads to the development of metabolic complications including global adiposity, adipocyte hypertrophy and its dysfunctionfrequently leading to central obesity. In turn, obesity leads to genetic polymorphism (A-953G SNP) causing underexpression of AQP7 in adipocytes [226]. Furthermore, AQP7 deficiency results in increased glycerol concentration inside adipocytes and increased activity of glycerol-3-phosphate leading to preferential re-esterification of FFAs. This sequence of events enhances progressive triacylglycerol accumulation and adipocyte hypertrophy.

\section{MicroRNAs Expressed in Adipose Tissue Are Involved in Molecular Mechanism of Metabolic Diseases}

The function and metabolism of cells are tightly controlled and depend on gene expression, regulated both at the transcriptional and post-transcriptional levels. Small, noncoding RNA molecules called microRNAs play an important role in the post-transcriptional regulation of gene expression and have been shown to play an important role in all cellular processes. Deregulation in the expression of microRNAs leads to cell dysfunction and the development of disease states [227].

The biology of adipose tissue cells has been found to be regulated by microRNA [228]. In adipocytogenesis, microRNAs control all stages of cell differentiation. For example, the switch between the differentiation of mesenchymal stem cells towards adipogenic vs. osteogenic lineages is controlled by miR-204 through suppressing of Runx2 and DVL3 expression [229]. Preadipocyte differentiation can be both inhibited (e.g., by miR-125a-5p, which negatively regulates STAT-3 [230]) and enhanced (e.g., by miR-183 which targets LRP6 [231]) by microRNAs. Many studies highlight the importance of microRNAs in the regulation of brown, brite and white adipose tissue differentiation [228]. Moreover, in mice with adipose tissue specific DICER 
(a key protein in microRNA biogenesis) knockout whitening of brown adipose tissue was observed [232]. In addition to the single examples of microRNAs involved in adipocytogenesis are given above, there are several dozen other microRNAs in the literature, the expression level of which depends on the degree of differentiation of fat cells [233]. The expression of microRNAs, as well as the expression of genes encoding proteins, must therefore be controlled. One of the factors regulating the level of microRNA expression are gonadal steroids [33-37]. As shown in Table 1, the level of several microRNAs important in the development and differentiation of adipose tissue can be regulated by sex hormones.

Table 1. Gonadal steroid-regulated microRNAs involved in adipogenic differentiation.

\begin{tabular}{|c|c|c|c|}
\hline miRNA & Regulation & Study Model & References \\
\hline let-7a & $\mathrm{A} ; \mathrm{E}$ & 3T3-L1 & [234] \\
\hline let-7c & $\mathrm{A} ; \mathrm{E}$ & 3T3-L1 & [234] \\
\hline miR-9 & $\mathrm{E}$ & 3T3-L1 & [235] \\
\hline miR-17-5p & $\mathrm{A} ; \mathrm{E} ; \mathrm{P}$ & 3T3-L1 & [236] \\
\hline miR-21 & $\mathrm{A} ; \mathrm{E} ; \mathrm{P}$ & BMSCs & [237] \\
\hline miR-22 & A & knockout mice; primary brown adipocytes & [238] \\
\hline $\operatorname{miR}-23 b$ & $\mathrm{~A} ; \mathrm{E} ; \mathrm{P}$ & knockout mice; primary pre-adipocytes & [239] \\
\hline miR-24 & $\mathrm{E}$ & 3T3-L1 & [240] \\
\hline miR-26 & $\mathrm{E} ; \mathrm{P}$ & C57Bl/6 mice; SVF & [241] \\
\hline $\operatorname{miR}-27 a$ & $\mathrm{~A} ; \mathrm{E}$ & mature adipocytes; SVCs; MSC & [242] \\
\hline miR-29 & $\mathrm{A} ; \mathrm{E}$ & hMADS & [243] \\
\hline miR-30d & A; E & hMADS & [244] \\
\hline miR-32 & A & MCPIP1; 3T3-L1 & [245] \\
\hline miR-124 & A & hMSC & [246] \\
\hline miR-128 & A & hMSC & [247] \\
\hline miR-129 & E & C57BLKS/J mouse & [248] \\
\hline miR-133 & A & 3T3-L1 & [249] \\
\hline miR-143 & $\mathrm{E}$ & 3T3-L1 & [250] \\
\hline miR-144 & $\mathrm{E}$ & 3T3-L1; mice & [251] \\
\hline miR-150 & $\mathrm{E}$ & pre-adipocytes from Qinchuan cattle & [252] \\
\hline miR-182 & $\mathrm{A} ; \mathrm{E}$ & 3T3-L1; VAT & [253] \\
\hline miR-203 & $\mathrm{A} ; \mathrm{E}$ & Knockout mice; SVF & [84] \\
\hline $\mathrm{miR}-204$ & A & 3T3-L1 & [254] \\
\hline miR-206 & $\mathrm{E}$ & 3T3-L1 & [255] \\
\hline miR-221 & A & SGBS & [256] \\
\hline $\mathrm{miR}-342$ & $\mathrm{E}$ & hMSC; 3T3-L1 & [257] \\
\hline $\operatorname{miR}-363$ & A & ADSCs & [231] \\
\hline miR-375 & $A ; E$ & 3T3-L1 & [258] \\
\hline $\operatorname{miR}-378$ & $E$ & Bovine preadipocytes & [259] \\
\hline
\end{tabular}

Abbreviations: A, androgens; E, estrogens; P, progesterone. Table 1 is based on [34-37] (Regulation) and references given in the table (miRNA, Metabolic Disorders). 
The function of microRNA in fat cells is not limited to controlling cell differentiation. Numerous works document the influence of microRNAs on the metabolism and function of fat cells [228]. For example, the level of UCP1 protein that modulates glucose metabolism and heat production has been shown to be regulated by miR-191a-5p, miR-204 and miR-455 [260-262]. The level of GLUT4, the protein responsible for glucose uptake in BAT cells, is regulated directly by miR-93 and miR-218 [263,264]. A correlation between the expression level of miR-222, the estrogen receptor and GLUT4 has also been demonstrated [265]. microRNAs which expression can be regulated by androgens (miR-124 and miR-145) and estrogens (miR-30c) are implicated in thermogenesis regulation by targeting MCT1, LDH and RIP140, respectively [266-268]. MCT1 expression is also modulated by miR-342-3p [269]. On the other hand, miR-124 is one of the modulators of fat metabolism by inhibiting TLG expression [270]. Another androgen-regulated microRNA (miR-128) is involved in lipid accumulation via repressing SIRT1 expression [271]. In WAT cells, progesterone-regulated miR-193b controls adiponectin production [272].

Apart from maintaining the proper energy balance of the body, adipose tissue also performs a secretory function. Autocrine, paracrine or endocrine communication in adipose tissue occurs via exosomes-vesicles produced and released, among others, by adipocytes [273]. Exosomes participate in intercellular and interorgan communication by transporting bioactive molecules produced in fat cells to their target cells. One type of active molecule transported by exosomes are microRNAs. Studies on mice with a knockout of the DICER protein coding gene and on patients with lipodystrophy have shown that fat cells (especially BAT) are the major source of circulating exosomal microRNAs [15]. Exosomes secreted by adipose tissue can be identified in biological fluids by measuring adipocyte-enriched microRNAs (let-7b, miR-16, miR-103, miR-146b, miR-148a, miR-201, miR-221 and miR-222) [274]. Although a direct relationship between sex hormones and microRNAs expressed in adipocytes has not been established in adipocyte cells, the expression of most of them can be regulated by gonadal steroids [34-37]. There is evidence that adipocyte-derived extracellular vehicles can influence the function of liver, skeletal muscle, heart, lungs, hypothalamus and ovary $[274,275]$. The composition and content of exosomes strongly depend on the physiological state of the body and there is increasing evidence that adipose-derived vehicles play an important role in the dysregulation of the body's energy balance and metabolism [273]. Knowledge on the role of miRNAs in the regulation of metabolism and development of metabolic diseases is developing intensively [276]. The role of miRNAs in the development of metabolic diseases such as obesity, T2D, polycystic ovary syndrome, nonalcoholic fatty disease, cardiovascular and inflammatory diseases was recently reviewed [277-283]. Moreover, the expression of aquaporin isoforms associated with metabolic diseases is also regulated by microRNAs [284]. Studies describing the regulation of microRNAs expression by gonadal steroids [34-37] and the association of microRNAs with metabolic diseases [277-281,283-285], allowed to identify the most important microRNAs in metabolic diseases which expression level may be regulated by sex hormones (Table 2).

Table 2. Gonadal steroid-regulated microRNAs involved in metabolic diseases and AQPs functioning.

\begin{tabular}{cccc}
\hline miRNA & Regulation & Metabolic Disoders & References \\
\hline let-7a & E & PCOS & {$[279]$} \\
\hline let-7b & E & O, T2Ds, PCOS & {$[277-279]$} \\
\hline let-7c & A, E & O, T2Ds, PCOS & {$[277-279]$} \\
\hline miR-1 & A & T2D, AQP & {$[278,284]$} \\
\hline miR-9 & E & PCOS, NAFLD & {$[279,280]$} \\
\hline miR-15 & E & PCOS, NAFLD, CVD & {$[279,280,282]$} \\
\hline miR-16 & E & PCOS,NAFLD, AQP & {$[279,280,284]$} \\
\hline
\end{tabular}


Table 2. Cont.

\begin{tabular}{|c|c|c|c|}
\hline miRNA & Regulation & Metabolic Disoders & References \\
\hline miR-19 & A & PCOS, NAFLD, AQP, CVD & {$[279,280,282,284]$} \\
\hline miR-20 & $\mathrm{P}$ & $\mathrm{T} 2 \mathrm{D}$ & [278] \\
\hline miR-21 & $\mathrm{A}, \mathrm{E}, \mathrm{P}$ & PCOS, NAFLD, AQP & {$[279,280,284]$} \\
\hline miR-22 & A & $\mathrm{O}, \mathrm{AQP}$ & {$[277,284]$} \\
\hline $\mathrm{miR}-23 \mathrm{a}$ & $\mathrm{P}$ & PCOS, AQP, CVD & {$[279,282,284]$} \\
\hline miR-24 & $\mathrm{E}$ & PCOS, NAFLD, CVD & {$[279,280,282]$} \\
\hline miR-26a & A & O, PCOS, NAFLD & {$[277,279,280]$} \\
\hline $\mathrm{miR}-27$ & $\mathrm{~A}, \mathrm{E}$ & PCOS, NAFLD, CVD & {$[279,280,282]$} \\
\hline miR-29 & A, E, P & O, T2D, PCOS, NAFLD, AQP & {$[277-280,284]$} \\
\hline miR-30d & $\mathrm{A}, \mathrm{E}$ & T2D, PCOS, NAFLD & [278-280] \\
\hline miR-32 & A & PCOS, AQP, CVD & {$[279,282,284]$} \\
\hline miR-92 & $\mathrm{E}$ & PCOS & [279] \\
\hline miR-99 & A & PCOS, NAFLD & {$[279,280]$} \\
\hline miR-100 & A & PCOS & [279] \\
\hline miR-124a & A & T2D, PCOS, AQP & {$[278,279,284]$} \\
\hline miR-125 & A, E & PCOS, NAFLD, CVD & {$[279,280,282]$} \\
\hline miR-128 & A & PCOS & [279] \\
\hline miR-133a & A & T2D, PCOS & {$[278,279]$} \\
\hline miR-135 & $\mathrm{A}, \mathrm{E}$ & PCOS & [279] \\
\hline miR-141 & $\mathrm{A}, \mathrm{E}$ & PCOS & {$[277,279]$} \\
\hline miR-142 & $\mathrm{P}$ & $\mathrm{O}, \mathrm{PCOS}, \mathrm{CVD}$ & {$[277,279,282]$} \\
\hline miR-143 & $\mathrm{E}$ & $\mathrm{O}$ & [277] \\
\hline $\mathrm{miR}-144$ & $\mathrm{E}$ & O, PCOS, NAFLD, AQP & {$[277,279,280,284]$} \\
\hline $\mathrm{miR}-145$ & A & T2D, AQP & {$[278,284]$} \\
\hline miR-146 & $\mathrm{P}$ & PCOS, NAFLD & {$[279,280]$} \\
\hline miR-148 & A & $\mathrm{O}$ & [277] \\
\hline miR-149 & $\mathrm{E}$ & PCOS, NAFLD & {$[279,280]$} \\
\hline miR-151 & $E$ & PCOS & [279] \\
\hline miR-182 & $\mathrm{A}, \mathrm{E}$ & PCOS, NAFLD, CVD & {$[279,280,282]$} \\
\hline miR-185 & A & PCOS, AQP & {$[279,284]$} \\
\hline miR-193 & $\mathrm{P}$ & PCOS & [279] \\
\hline miR-195 & $\mathrm{E}$ & PCOS, AQP & {$[279,284]$} \\
\hline miR-200 & $\mathrm{P}$ & T2D, PCOS, NAFLD & [278-280] \\
\hline miR-203 & $\mathrm{A}, \mathrm{E}$ & PCOS, NAFLD, AQP & {$[279,280,284]$} \\
\hline miR-221 & A & O, PCOS, NAFLD, CVD & {$[277,279,280,282]$} \\
\hline $\mathrm{miR}-222$ & A & $\mathrm{O}, \mathrm{PCOS}, \mathrm{NAFLD}, \mathrm{CVD}$ & {$[277,279,280,282]$} \\
\hline miR-320 & E & PCOS, AQP & {$[279,284]$} \\
\hline miR-342 & $\mathrm{E}$ & PCOS & [279] \\
\hline
\end{tabular}


Table 2. Cont.

\begin{tabular}{cccc}
\hline miRNA & Regulation & Metabolic Disoders & References \\
\hline miR-365 & E & PCOS & {$[279]$} \\
\hline miR-375 & A, E & O, T2D & {$[277,278]$} \\
\hline miR-423 & A, E & O & {$[277]$} \\
\hline miR-432 & E & O & {$[277]$} \\
\hline miR-486 & E & PCOS & {$[279]$} \\
\hline miR-504 & E & O & {$[277]$} \\
\hline miR-520 & E & O & {$[277]$} \\
\hline miR-548 & E & O & {$[277]$} \\
\hline miR-690 & A & T2D & {$[278]$} \\
\hline
\end{tabular}

Abbreviations: A, androgens; E, estrogens; P, progesterone; O, obesity; T2D, type 2 diabetes; PCOS, polycystic ovary syndrome; NAFLD, non-alcoholic fatty liver disease; AQP, aquaporins; CVD, cardiovascular diseases. Table 2 is based on [34-37] (Regulation) and the other references are given in the table (miRNA, Metabolic Disorders).

\section{Discussion}

Several aspects of adipose tissue biology are regulated differently in males and females, influencing their predisposition to metabolic disorders. Moreover, disturbances in gonadal hormone homeostasis can deeply affect energy balance, glucose and lipid metabolism, reinforcing the need for personalized sex-specific approaches in management of metabolic abnormalities. This kind of approach should take into account the possibilities of regulation of gonadal steroids action at adipose tissue level. Below, we summarize the most promising, relatively novel therapeutic tactics fitting into the trend of personalized management of metabolic disorders. We also place a great emphasis here on these drug targets which are still uncommonly considered in the field.

Aquaporins are emerging drug targets to prevent and counteract metabolic abnormalities $[43,286]$. Among the substances that could improve adipocyte functioning in both sexes are thiazolidinediones (being insulin sensitizers) acting as PPAR $\gamma$ agonists, which are proven to upregulate AQP7 [43,199,200,287].

Considering the effects of gonadal hormones on the ability of the organism to respond to insulin, it is reasonable to consider the use of insulin sensitizers to alleviate the steroidtuned insulin resistance. One of them is metformin which is commonly used in T2D [288]. As mentioned in Section Insulin sensitivity, estradiol is able to enhance the activity of adenosine monophosphate-activated protein kinase (AMPK) through ER [121]. In turn, one of the molecular mechanisms of metformin action includes AMPK activation [288]. From this perspective, metformin administration seems a reasonable choice in case of prevention of insulin resistance especially in patients with E2 deficits.

Other promising substances are inositols, which not only improve insulin sensitivity but also regulate steroidogenesis in women, and consequently may refine ovulatory function in hyperandrogenic females [289,290]. Interestingly, the use of myoinositol improves sperm function, boosting sperm motility in patients with altered semen parameters (in asthenozoospermia) [291]. It is worth noticing that the sperm motility and volume, affecting the observed fertility, are regulated by aquaporins [292]. In connection with the above, male patients with idiopathic infertility could also take advantage of inositol supplementation. Thus, inositols may find clinical applications in assisted reproductive treatment and counteracting metabolic dysfunctions in both men and women [293].

Other active substances that can be used to improve endocrine function of adipocytes in cases of corticosteroid imbalance are those affecting the immune system. Considering the significant role of adiponectin in counteracting inflammatory processes and increasing the sensitivity of tissues to insulin, this adipokine may be considered as a potential drug $[147,290]$. Exogenous adiponectin supplementation in early pregnant individuals 
may help to avoid the metabolic syndrome of adult female offspring, according to the recent studies on a mouse PCOS model [294]. A probable mechanism underlying this effect is related to the activation of the AMPK/PI3K-Akt signaling pathway in PCOS offspring mice [294].

Since AQPs have been recognized as functionally involved in immune cell activity such as priming and inflammasome activation, transendothelial migration and phagocytosis, development of $\mathrm{AQP}$-oriented drugs gives a promising opportunity in future therapies against metabolic diseases [203]. Up to date, several AQP modulators have been proposed and even patented for use for diagnostic and therapeutic purposes [295,296]. Nevertheless, the lack of selectivity and toxic side effects prevent most of these substances from being subjected to extensive clinical testing. Among the most promising AQP modulators, which are relatively safe and able to effectively prevent inflammation, are the gold(III) bipyridyl compound Auphen and compounds DFP00173, Z433927330 and HTS13286. The physiological effects of their administration are summarized in [203]. An alternative AQPs-targeted approach can be based on modulation of aquaporins at the post-transcriptional level.

A global regulator of gene expression are microRNAs. Although sex-related differences in the expression profile of microRNAs are still poorly understood [282], there is evidence that both sex chromosomes and sex hormones can cause differences in microRNAs expression [33]. At the same time, microRNAs can be a link between coexisting metabolic diseases, as each microRNA can interact with dozens of targets. Thus, microRNAs represent promising therapeutic target itself. Our analysis (Table 2) suggests that miR-29 may be one of the therapeutic targets, as its deregulation is associated with all analyzed metabolic disorders. Equally interesting, in the context of the role of adipose tissue in the development of metabolic diseases, are adipocyte-enriched microRNAs (let-7b, miR-16, miR-146b, miR-221 and miR-222) associated with metabolic disorders.

Recently, significant attention has been drawn to application of flavonoids to attenuate chronic inflammation $[297,298]$. It has been reported that natural flavonoids (e.g., naringenin, rutin and quercetin) can influence modulatory effects on inflammasomes associated with the initiation and progression of chronic disorders, including metabolic ones. Regardless of sex, inflammasome targeting via flavonoids can bring advantageous effects on health. As an example, naringenin increases the concentration of enzymes removing reactive oxygen species and exhibits cytoprotective and anti-inflammatory effects via targeting mitochondrial potassium channels [299]. Naringenin can also modulate the activity of enzymes involved in interconversion of steroid hormones ( $3 \beta$-hydroxysteroid dehydrogenase and $17 \beta$-hydroxysteroid dehydrogenase), as summarized in [290]. Thus, it can be useful in downregulation of androgen production in women suffering hyperandrogenemia.

Other possible strategy to improve functioning of adipose tissue in metabolic diseases is to target adipocyte mitochondria, due to their substantial roles in the regulation of wholebody energy homeostasis, control of insulin sensitivity and glucose metabolism or crosstalk between muscles and adipose tissues [300]. Here, possible therapeutic solutions include the activation of BAT thermogenesis and WAT browning [301] and the application of mitochondrial-targeted antioxidants (such as vitamin $\mathrm{E}, \mathrm{N}$-acetylcysteine, glutathione and coenzyme Q10). It is worth noticing that WAT browning may be induced by the chronic treatment with $\beta 3$-adrenergic activators or the PPAR $\gamma$ agonist thiazolidinedione [300], which was also reported in this review as an AQP-oriented drug. In turn, affecting the adaptive thermogenesis in brown adipose tissue can also be achieved by the administration of $\beta$-adrenergic agonists affecting sympathetic nervous system and promoting increased BAT activity [301]. Women have more active brown adipose tissue (BAT) than men [302], and this relation may be partly caused by the differences in sex hormone levels. Estradiol can activate thermogenesis in BAT (promoting energy expenditure) through the sympathetic nervous system (SNS) due to its ability to inhibit AMPK through $\alpha$-ER selectively in the ventromedial nucleus of the hypothalamus (VMH) [302,303]. Even the physiological changes in E2 levels across the menstrual cycle affect thermogenesis in women. Thus, the disruption of the female hormonal balance impairs the energy homeostasis also at the level 
of VMH AMPK-SNS-BAT axis which may contribute to the tendency to obesity in women with estrogen deficits [303]. Moreover, both rodent models as well as the characteristics of the PCOS patients suggest that BAT thermogenesis is negatively associated with androgen levels [304,305].

Coming back to the possibilities of sex-dependent therapies of metabolic diseases, one may consider the potential procedures dedicated to modulate the activity or levels of steroid-converting enzymes in human adipose tissues. With the proceeding fat accumulation in obese men, there is an increase of aromatase activity that is associated with a greater conversion of testosterone to estradiol (Figure 2). Thus, the resulting depression of testosterone concentrations give rise to the increased preferential deposition of abdominal fat, which deepens the hypogonadal state [306]. Another enzyme that can serve as a target in therapies against metabolic abnormalities, is type $1217 \beta$-HSD, which is reported as mainly responsible for the conversion of estrone into estradiol according to the in vitro studies [307] (Figure 2). The regulation of expression level of this enzyme, which is maximally expressed at the end of the differentiation in human adipocytes, could represent a mechanism that allows a time-dependent and cell type-specific tuning of estrogen production [307].

The eventual solution to the metabolic complications accompanied by sex hormone imbalance seems to be offered by the introduction of hormone replacement therapies. The administration of gonadal hormones could be considered in the groups of elderly people, patients with morbid obesity, women suffering estrogen depletion (e.g., postmenopausal women) and men exhibiting androgen deficits (hypogonadal men). According to the literature [68,308], estradiol supplementation seems to be efficient in prevention of metabolic consequences of the long-term estrogen deficiency (as in the case of ovariectomy or postmenopausal women). Estradiol is one of the factors regulating energy homeostasis by modulating both energy expenditure (modulation of BAT thermogenesis) and food intake. E2 can inhibit feeding while acting in arcuate nucleus of the hypothalamus, whereas estrogen deprivation is related to hyperphagia and, frequently, weight gain [309,310]. According to the ovariectomized mice model, these effects can be reversed by E2 replacement therapy [309]. Moreover, as suggested by a mouse model [311], supplementation of individuals exhibiting reduced ovarian functions with estrogen can revert such effects, such as increased 5'adenosine monophosphate-activated protein kinase (AMPK) phosphorylation, high expression level of the genes encoding adiponectin, UCP2 and PPAR $\gamma$ coactivator $1 \alpha$ (PGC-1 $\alpha$ ) and low resistin expression in WAT. Additionally, estradiol treatment enables attenuating the decrease of perilipin in VAT after bilateral ovariectomy [308], which is an important outcome, since perilipin is the principal protein controlling the lipase access to stored triglycerides and consequently regulating lipolysis [308]. To sum up, estradiol replacement seems to be a promising therapeutic solution for women suffering E2 depletion. However, introduction of this kind of therapy should be highly personalized and take into account the possible side effects of chronic hormone supplementation.

The testosterone replacement therapy (TRT) is particularly advantageous in hypogonadal men, where its application results in enhanced energy metabolism, increased fat-free mass, decreased level of inflammatory markers and improved sexual function [155,312-314]. The improvement of patients' health is especially evident in hypogonadal men with T2D [315], for whom testosterone replacement therapy for 1 year or longer allows increasing their survival probability. Importantly, beside the benefits of TRT therapy in this group of patients at the metabolic and sexual levels, it is also advantageous in case of infections (e.g., viral diseases) [175] due to the possible mitigation of the damaging inflammatory response to a given pathogen without hampering the immune system's response.

As a general comment, it is clear from the literature that, while the popular rodent models admittedly give interesting inferences, they are not ideal when considering the subtle dynamics of hormone-regulated processes. In this review, we only mention some, subjectively chosen, reports on mice or rat models, only when they highlight the most important aspects of the discussed processes. The results of human studies often contrast those obtained in animals, which may resemble the significance of species-inherent details 
of hormonal balance. To explain these discrepancies, extensive in vitro studies on molecular mechanisms are paramount. From this perspective, at the initial stages of research on human physiology of sex hormone-regulated processes, it seems that the best choice is to carry out experiments in vitro on human cells, if it is possible.

\section{Conclusions}

The well-known guidelines to prevent and alleviate metabolic disorders include a set of lifestyle choices referring to dietary habits, exercise and caloric restriction. Their impact is, however, far below expectations in the general population. To reach satisfactory results in counteracting versatile abnormalities in energy, glucose and lipid homeostasis, novel therapeutic strategies should be proposed. This is where personalized medicine procedures can be particularly useful. According to the complex mechanisms responsible for sexdimorphic regulation of adipose tissue functioning, the novel therapeutic solutions should take into account the sex of the patient and the current status in their hormonal balance. In such strategy, not only should the conventional biochemical agents be considered as molecular targets but also the more fundamental ones such as miRNAs. On the other hand, aquaporins emerge as novel biologic targets in sex-specific management of metabolic diseases. Recognition of active substances affecting these specific targets offers a promise for the management of a large spectrum of clinical disorders including metabolic and energy balance diseases.

Author Contributions: Conceptualization, A.W.-J.; formal analysis, G.S.; investigation, A.W.-J., A.L. and G.S.; resources, A.W.-J., A.L. and G.S.; data curation, A.W.-J., A.L. and G.S.; writing-original draft preparation, A.W.-J. and A.L.; writing-review and editing, A.W.-J., A.L. and G.S.; visualization, A.W.-J. and A.L.; supervision, G.S.; project administration, A.W.-J.; and funding acquisition, A.W.-J. All authors have read and agreed to the published version of the manuscript.

Funding: This research was funded by the Silesian University of Technology grant No. 04/040/SDU/ 10-22-01 from the Excellence in Science Initiative for A.W.-J.

Institutional Review Board Statement: Not applicable.

Informed Consent Statement: Not applicable.

Conflicts of Interest: The authors declare no conflict of interest.

\section{Abbreviations}

The following abbreviations are used in this manuscript:

$\begin{array}{ll}\text { ACC1 } & \text { acetyl-CoA carboxylase } 1 \\ \text { AKR1C } & \text { aldo-keto reductase 1C enzyme } \\ \text { AKT } & \text { protein kinase B } \\ \text { AMPK } & 5^{\prime} \text { AMP-activated protein kinase } \\ \text { AR } & \text { adrenergic receptors } \\ \text { ATGL } & \text { adipose triglyceridelipase } \\ \text { BAT } & \text { brown adipose tissue } \\ \text { 3 } \beta \text {-HSD } & \text { 3 } \beta \text {-hydroxysteroid dehydrogenase } \\ 11 \beta \text {-HSD1 } & 11 \beta \text {-hydroxysteroid dehydrogenase type } 1 \\ \text { 17 } \beta \text {-HSD } & 17 \beta \text {-hydroxysteroid dehydrogenase } \\ \text { CD68 } & \text { cluster of differentiation } 68 \\ \text { CRP } & \text { C-reactive protein } \\ \text { CYP11A1 } & \text { cholesterol side-chain cleavage enzyme } \\ \text { CYP17A1 } & \text { steroid } 17 \alpha \text {-monooxygenase } \\ \text { DHEA } & \text { dehydroepiandrosterone }\end{array}$




$\begin{array}{ll}\text { DHEA-S } & \text { dehydroepiandrosterone sulfate } \\ \text { DHT } & \text { dihydrotestosterone } \\ \text { E1 } & \text { estrone } \\ \text { E2 } & 17 \beta \text { estradiol } \\ \text { E3 } & \text { estriol } \\ \text { FAS } & \text { fatty acid synthase } \\ \text { FFA } & \text { free fatty acids } \\ \text { GLUT4 } & \text { glucose transporter type } 4 \\ \text { IRE } & \text { insulin response element } \\ \text { IRS-1 } & \text { insulin receptor substrate 1 } \\ \text { HSL } & \text { hormone-sensitive lipase } \\ \text { LPL } & \text { lipoprotein lipase activity } \\ \text { NAFLD } & \text { non-alcoholic fatty liver disease } \\ \text { NF- } \kappa \text { B } & \text { nuclear factor kappa-light-chain-enhancer of activated B cells } \\ \text { PBMCs } & \text { peripheral blood mononuclear cells } \\ \text { PCOS } & \text { polycystic ovary syndrome } \\ \text { PKC } \zeta & \text { protein kinase C } \zeta \\ \text { PPAR } \gamma & \text { peroxisome proliferator-activated receptor } \gamma \\ \text { SAT } & \text { subcutaneous adipose tissue } \\ \text { SCD1 } & \text { stearoyl-CoA desaturase 1 } \\ \text { SULT2A1 } & \text { dehydroepiandrosterone sulfotransferase } \\ \text { T } & \text { testosterone } \\ \text { T2D } & \text { diabetes mellitus type 2 } \\ \text { TLR } & \text { Toll-Like Receptors } \\ \text { TNF } \alpha & \text { tumor necrosis factor } \\ \text { TRT } & \text { testosterone replacement therapy } \\ \text { VAT } & \text { visceral adipose tissue } \\ \text { WAT } & \text { White adipose tissue } \\ & \end{array}$

\section{References}

1. Klaus, S. Adipose Tissue; CRC Press: Boca Raton, FL, USA, 2001.

2. Choe, S.S.; Huh, J.Y.; Hwang, I.J.; Kim, J.I.; Kim, J.B. Adipose tissue remodeling: Its role in energy metabolism and metabolic disorders. Front. Endocrinol. 2016, 7, 30. [CrossRef] [PubMed]

3. Siiteri, P.K. Adipose tissue as a source of hormones. Am. J. Clin. Nutr. 1987, 45, 277-282. [CrossRef] [PubMed]

4. Kershaw, E.E.; Flier, J.S. Adipose tissue as an endocrine organ. J. Clin. Endocrinol. Metab. 2004, 89, 2548-2556. [CrossRef]

5. Gastaldelli, A.; Gaggini, M.; DeFronzo, R.A. Role of adipose tissue insulin resistance in the natural history of type 2 diabetes: Results from the San Antonio Metabolism Study. Diabetes 2017, 66, 815-822. [CrossRef] [PubMed]

6. Parker, R. The role of adipose tissue in fatty liver diseases. Liver Res. 2018, 2, 35-42. [CrossRef]

7. Buzzetti, E.; Pinzani, M.; Tsochatzis, E.A. The multiple-hit pathogenesis of non-alcoholic fatty liver disease (NAFLD). Metabolism 2016, 65, 1038-1048. [CrossRef]

8. Gaggini, M.; Morelli, M.; Buzzigoli, E.; DeFronzo, R.A.; Bugianesi, E.; Gastaldelli, A. Non-alcoholic fatty liver disease (NAFLD) and its connection with insulin resistance, dyslipidemia, atherosclerosis and coronary heart disease. Nutrients 2013, 5, 1544-1560. [CrossRef]

9. Rosso, C.; Kazankov, K.; Younes, R.; Esmaili, S.; Marietti, M.; Sacco, M.; Carli, F.; Gaggini, M.; Salomone, F.; Møller, H.J.; et al. Crosstalk between adipose tissue insulin resistance and liver macrophages in non-alcoholic fatty liver disease. J. Hepatol. 2019, 71, 1012-1021. [CrossRef]

10. Cordeiro, A.; Costa, R.; Andrade, N.; Silva, C.; Canabrava, N.; Pena, M.J.; Rodrigues, I.; Andrade, S.; Ramalho, A. Does adipose tissue inflammation drive the development of non-alcoholic fatty liver disease in obesity? Clin. Res. Hepatol. Gastroenterol. 2020, 44, 394-402. [CrossRef]

11. Hall, J.E.; do Carmo, J.M.; da Silva, A.A.; Wang, Z.; Hall, M.E. Obesity-induced hypertension: Interaction of neurohumoral and renal mechanisms. Circ. Res. 2015, 116, 991-1006. [CrossRef]

12. Asferg, C.L.; Nielsen, S.J.; Andersen, U.B.; Linneberg, A.; Møller, D.V.; Hedley, P.L.; Christiansen, M.; Goetze, J.P.; Esler, M.; Jeppesen, J.L. Relative atrial natriuretic peptide deficiency and inadequate renin and angiotensin II suppression in obese hypertensive men. Hypertension 2013, 62, 147-153. [CrossRef]

13. Candela, J.; Wang, R.; White, C. Microvascular endothelial dysfunction in obesity is driven by macrophage-dependent hydrogen sulfide depletion. Arterioscler. Thromb. Vasc. Biol. 2017, 37, 889-899. [CrossRef]

14. Vilahur, G.; Ben-Aicha, S.; Badimon, L. New insights into the role of adipose tissue in thrombosis. Cardiovasc. Res. 2017, 113, 1046-1054. [CrossRef] 
15. Thomou, T.; Mori, M.A.; Dreyfuss, J.M.; Konishi, M.; Sakaguchi, M.; Wolfrum, C.; Rao, T.N.; Winnay, J.N.; Garcia-Martin, R.; Grinspoon, S.K.; et al. Adipose-derived circulating miRNAs regulate gene expression in other tissues. Nature 2017, 542, 450-455. [CrossRef]

16. Xie, Z.; Wang, X.; Liu, X.; Du, H.; Sun, C.; Shao, X.; Tian, J.; Gu, X.; Wang, H.; Tian, J.; et al. Adipose-derived exosomes exert proatherogenic effects by regulating macrophage foam cell formation and polarization. J. Am. Heart Assoc. 2018,7 , e007442. [CrossRef]

17. King, A.L.; Polhemus, D.J.; Bhushan, S.; Otsuka, H.; Kondo, K.; Nicholson, C.K.; Bradley, J.M.; Islam, K.N.; Calvert, J.W.; Tao, Y.X.; et al. Hydrogen sulfide cytoprotective signaling is endothelial nitric oxide synthase-nitric oxide dependent. Proc. Natl. Acad. Sci. USA 2014, 111, 3182-3187. [CrossRef]

18. Kolluru, G.K.; Shen, X.; Kevil, C.G. Reactive sulfur species: A new redox player in cardiovascular pathophysiology. Arterioscler. Thromb. Vasc. Biol. 2020, 40, 874-884. [CrossRef] [PubMed]

19. Ying, W.; Riopel, M.; Bandyopadhyay, G.; Dong, Y.; Birmingham, A.; Seo, J.B.; Ofrecio, J.M.; Wollam, J.; Hernandez-Carretero, A.; $\mathrm{Fu}, \mathrm{W} . ;$ et al. Adipose tissue macrophage-derived exosomal miRNAs can modulate in vivo and in vitro insulin sensitivity. Cell 2017, 171, 372-384. [CrossRef]

20. Oikonomou, E.K.; Antoniades, C. The role of adipose tissue in cardiovascular health and disease. Nat. Rev. Cardiol. 2019, 16, 83-99. [CrossRef]

21. Eder, P.; Adler, M.; Dobrowolska, A.; Kamhieh-Milz, J.; Witowski, J. The role of adipose tissue in the pathogenesis and therapeutic outcomes of inflammatory bowel disease. Cells 2019, 8, 628. [CrossRef]

22. Zielińska, A.; Siwiński, P.; Sobolewska-Włodarczyk, A.; Wiśniewska-Jarosińska, M.; Fichna, J.; Włodarczyk, M. The role of adipose tissue in the pathogenesis of Crohn's disease. Pharmacol. Rep. 2019, 71, 105-111. [CrossRef] [PubMed]

23. Collins, K.H.; Lenz, K.L.; Pollitt, E.N.; Ferguson, D.; Hutson, I.; Springer, L.E.; Oestreich, A.K.; Tang, R.; Choi, Y.R.; Meyer, G.A.; et al. Adipose tissue is a critical regulator of osteoarthritis. Proc. Natl. Acad. Sci. USA 2021, 118, e2021096118. [CrossRef] [PubMed]

24. Zapata-Linares, N.; Eymard, F.; Berenbaum, F.; Houard, X. Role of adipose tissues in osteoarthritis. Curr. Opin. Rheumatol. 2021, 33, 84-93. [CrossRef] [PubMed]

25. Thijssen, E.; Van Caam, A.; Van Der Kraan, P.M. Obesity and osteoarthritis, more than just wear and tear: Pivotal roles for inflamed adipose tissue and dyslipidaemia in obesity-induced osteoarthritis. Rheumatology 2015, 54, 588-600. [CrossRef] [PubMed]

26. Newell-Fugate, A. The role of sex steroids in white adipose tissue adipocyte function. Reproduction 2017, 153, R133-R149. [CrossRef]

27. Chang, E.; Varghese, M.; Singer, K. Gender and sex differences in adipose tissue. Curr. Diabetes Rep. 2018, 18, 1-10. [CrossRef]

28. Monjo, M.; Pujol, E.; Roca, P. $\alpha 2$-to $\beta 3$-Adrenoceptor switch in 3T3-L1 preadipocytes and adipocytes: Modulation by testosterone, $17 \beta$-estradiol, and progesterone. Am. J. Physiol. Endocrinol. Metab. 2005, 289, E145-E150. [CrossRef]

29. Mansour, M.F.; Chan, C.W.J.; Laforest, S.; Veilleux, A.; Tchernof, A. Sex differences in body fat distribution. In Adipose Tissue Biology; Springer: New York, NY, USA, 2017; pp. 257-300.

30. Palmer, B.F.; Clegg, D.J. The sexual dimorphism of obesity. Mol. Cell. Endocrinol. 2015, 402, 113-119. [CrossRef]

31. Karastergiou, K.; Fried, S.K. Cellular mechanisms driving sex differences in adipose tissue biology and body shape in humans and mouse models. Sex Gend. Factors Affect. Metab. Homeost. Diabetes Obes. 2017, 1043, $29-51$.

32. Bredella, M.A. Sex differences in body composition. Sex Gend. Factors Affect. Metab. Homeost. Diabetes Obes. 2017, 1043, 9-27.

33. Sohrabji, F.; Selvamani, A. Sex differences in miRNA as therapies for ischemic stroke. Neurochem. Int. 2019, 127, 56-63. [CrossRef]

34. Bae, J.; Won, M.; Kim, D.Y.; Kim, J.H.; Kim, Y.M.; Kim, Y.T.; Nam, J.H.; Suh, D.S. Identification of differentially expressed microRNAs in endometrial cancer cells after progesterone treatment. Int. J. Gynecol. Cancer 2012, 22, 561-565. [CrossRef] [PubMed]

35. Nothnick, W.B. Non-coding RNAs in uterine development, function and disease. In Non-Coding RNA and the Reproductive System; Springer: Dordrecht, The Netherlands, 2016; pp.171-189.

36. Jansen, J.; Greither, T.; Behre, H.M. Androgen-regulated micrornas (Andromirs) as novel players in adipogenesis. Int. J. Mol. Sci. 2019, 20, 5767. [CrossRef]

37. Vivacqua, A.; Muoio, M.G.; Miglietta, A.M.; Maggiolini, M. Differential MicroRNA landscape triggered by estrogens in cancer associated fibroblasts (CAFs) of primary and metastatic breast tumors. Cancers 2019, 11, 412. [CrossRef] [PubMed]

38. Jasinski-Bergner, S.; Kielstein, H. Adipokines regulate the expression of tumor-relevant MicroRNAs. Obes. Facts 2019, 12, 211-225. [CrossRef]

39. Nussey, S.S.; Whitehead, S.A. Endocrinology: An Integrated Approach; BIOS Scientific Publishers: Oxford, UK, 2001.

40. Li, J.; Papadopoulos, V.; Vihma, V. Steroid biosynthesis in adipose tissue. Steroids 2015, 103, 89-104. [CrossRef] [PubMed]

41. Mooradian, A.D.; Morley, J.E.; Korenman, S.G. Biological actions of androgens. Endocr. Rev. 1987, 8, 1-28. [CrossRef]

42. Nelson, L.R.; Bulun, S.E. Estrogen production and action. J. Am. Acad. Dermatol. 2001, 45, S116-S124. [CrossRef]

43. Madeira, A.; Moura, T.F.; Soveral, G. Aquaglyceroporins: Implications in adipose biology and obesity. Cell. Mol. Life Sci. 2015, 72, 759-771. [CrossRef] [PubMed]

44. Kautzky-Willer, A.; Harreiter, J.; Pacini, G. Sex and gender differences in risk, pathophysiology and complications of type 2 diabetes mellitus. Endocr. Rev. 2016, 37, 278-316. [CrossRef] [PubMed] 
45. Escobar-Morreale, H.F. Polycystic ovary syndrome: Definition, aetiology, diagnosis and treatment. Nat. Rev. Endocrinol. 2018, 14, 270. [CrossRef] [PubMed]

46. Teede, H.J.; Misso, M.L.; Costello, M.F.; Dokras, A.; Laven, J.; Moran, L.; Piltonen, T.; Norman, R.J. Recommendations from the international evidence-based guideline for the assessment and management of polycystic ovary syndrome. Hum. Reprod. 2018, 33, 1602-1618. [CrossRef] [PubMed]

47. Dwyer, A.A.; Chavan, N.R.; Lewkowitz-Shpuntoff, H.; Plummer, L.; Hayes, F.J.; Seminara, S.B.; Crowley, W.F., Jr.; Pitteloud, N.; Balasubramanian, R. Functional hypogonadotropic hypogonadism in men: Underlying neuroendocrine mechanisms and natural history. J. Clin. Endocrinol. Metab. 2019, 104, 3403-3414. [CrossRef] [PubMed]

48. Zarotsky, V.; Huang, M.Y.; Carman, W.; Morgentaler, A.; Singhal, P.; Coffin, D.; Jones, T. Systematic literature review of the risk factors, comorbidities, and consequences of hypogonadism in men. Andrology 2014, 2, 819-834. [CrossRef] [PubMed]

49. Speiser, P.W.; White, P.C. Congenital adrenal hyperplasia. N. Engl. J. Med. 2003, 349, 776-788. [CrossRef]

50. El-Maouche, D.; Arlt, W.; Merke, D.P. Congenital adrenal hyperplasia. Lancet 2017, 390, 2194-2210. [CrossRef]

51. Dandona, P.; Dhindsa, S. Update: Hypogonadotropic hypogonadism in type 2 diabetes and obesity. J. Clin. Endocrinol. Metab. 2011, 96, 2643-2651. [CrossRef] [PubMed]

52. Bellastella, G.; Menafra, D.; Puliani, G.; Colao, A.; Savastano, S. How much does obesity affect the male reproductive function? Int. J. Obes. Suppl. 2019, 9, 50-64. [CrossRef]

53. Crisóstomo, L.; Pereira, S.C.; Monteiro, M.P.; Raposo, J.F.; Oliveira, P.F.; Alves, M.G. Lifestyle, metabolic disorders and male hypogonadism-A one-way ticket? Mol. Cell. Endocrinol. 2020, 516, 110945. [CrossRef]

54. Lizcano, F.; Guzmán, G. Estrogen deficiency and the origin of obesity during menopause. BioMed Res. Int. 2014, $2014,757461$. [CrossRef]

55. He, X.; Li, Z.; Tang, X.; Zhang, L.; Wang, L.; He, Y.; Jin, T.; Yuan, D. Age-and sex-related differences in body composition in healthy subjects aged 18 to 82 years. Medicine 2018, 97, e11152. [CrossRef] [PubMed]

56. Karpe, F.; Pinnick, K.E. Biology of upper-body and lower-body adipose tissue-link to whole-body phenotypes. Nat. Rev. Endocrinol. 2015, 11, 90. [CrossRef] [PubMed]

57. Nauli, A.M.; Matin, S. Why do men accumulate abdominal visceral fat? Front. Physiol. 2019, 10, 1486. [CrossRef] [PubMed]

58. Stefan, N. Causes, consequences, and treatment of metabolically unhealthy fat distribution. Lancet Diabetes Endocrinol. 2020, 8 , 616-627. [CrossRef]

59. Lumish, H.S.; O’Reilly, M.; Reilly, M.P. Sex differences in genomic drivers of adipose distribution and related cardiometabolic disorders: Opportunities for precision medicine. Arterioscler. Thromb. Vasc. Biol. 2020, 40, 45-60. [CrossRef] [PubMed]

60. Guglielmi, V.; Sbraccia, P. Obesity phenotypes: Depot-differences in adipose tissue and their clinical implications. Eat. Weight Disord. Stud. Anorex. Bulim. Obes. 2018, 23, 3-14. [CrossRef] [PubMed]

61. Geer, E.B.; Shen, W. Gender differences in insulin resistance, body composition, and energy balance. Gend. Med. 2009, 6, 60-75. [CrossRef] [PubMed]

62. Zore, T.; Palafox, M.; Reue, K. Sex differences in obesity, lipid metabolism, and inflammation-A role for the sex chromosomes? Mol. Metab. 2018, 15, 35-44. [CrossRef]

63. Heinonen, S.; Saarinen, L.; Naukkarinen, J.; Rodríguez, A.; Frühbeck, G.; Hakkarainen, A.; Lundbom, J.; Lundbom, N.; Vuolteenaho, K.; Moilanen, E.; et al. Adipocyte morphology and implications for metabolic derangements in acquired obesity. Int. J. Obes. 2014, 38, 1423-1431. [CrossRef]

64. Ofori, E.K.; Conde Alonso, S.; Correas-Gomez, L.; Carnero, E.A.; Zwygart, K.; Hugues, H.; Bardy, D.; Hans, D.; Dwyer, A.A.; Amati, F. Thigh and abdominal adipose tissue depot associations with testosterone levels in postmenopausal females. Clin. Endocrinol. 2019, 90, 433-439. [CrossRef]

65. Park, Y.M.; Erickson, C.; Bessesen, D.; Van Pelt, R.E.; Cox-York, K. Age-and menopause-related differences in subcutaneous adipose tissue estrogen receptor mRNA expression. Steroids 2017, 121, 17-21. [CrossRef]

66. Hetemäki, N.; Savolainen-Peltonen, H.; Tikkanen, M.J.; Wang, F.; Paatela, H.; Hämäläinen, E.; Turpeinen, U.; Haanpää, M.; Vihma, V.; Mikkola, T.S. Estrogen metabolism in abdominal subcutaneous and visceral adipose tissue in postmenopausal women. J. Clin. Endocrinol. Metab. 2017, 102, 4588-4595. [CrossRef] [PubMed]

67. Mayes, J.; Watson, G. Direct effects of sex steroid hormones on adipose tissues and obesity. Obes. Rev. 2004, 5, 197-216. [CrossRef] [PubMed]

68. Moreira-Pais, A.; Ferreira, R.; Neves, J.S.; Vitorino, R.; Moreira-Gonçalves, D.; Nogueira-Ferreira, R. Sex differences on adipose tissue remodeling: From molecular mechanisms to therapeutic interventions. J. Mol. Med. 2020, 98, 483-493. [CrossRef] [PubMed]

69. Crandall, D.L.; Busler, D.E.; Novak, T.J.; Weber, R.V.; Kral, J.G. Identification of estrogen receptor $\beta$ RNA in human breast and abdominal subcutaneous adipose tissue. Biochem. Biophys. Res. Commun. 1998, 248, 523-526. [CrossRef] [PubMed]

70. Heine, P.; Taylor, J.; Iwamoto, G.; Lubahn, D.; Cooke, P. Increased adipose tissue in male and female estrogen receptor- $\alpha$ knockout mice. Proc. Natl. Acad. Sci. USA 2000, 97, 12729-12734. [CrossRef] [PubMed]

71. Kumar, R.; McEwan, I.J. Allosteric modulators of steroid hormone receptors: Structural dynamics and gene regulation. Endocr. Rev. 2012, 33, 271-299. [CrossRef]

72. Park, C.J.; Zhao, Z.; Glidewell-Kenney, C.; Lazic, M.; Chambon, P.; Krust, A.; Weiss, J.; Clegg, D.J.; Dunaif, A.; Jameson, J.L.; et al. Genetic rescue of nonclassical ER $\alpha$ signaling normalizes energy balance in obese Er $\alpha$-null mutant mice. J. Clin. Investig. 2011, 121, 604-612. [CrossRef] 
73. Lu, X.; Peng, L.; Lv, M. Recent advance in the design of small molecular modulators of estrogen-related receptors. Curr. Pharm. Des. 2012, 18, 3421-3431. [CrossRef]

74. Tara, M.; Souza, S.C.; Aronovitz, M.; Obin, M.S.; Fried, S.K.; Greenberg, A.S. Estrogen regulation of adiposity and fuel partitioning: Evidence of genomic and non-genomic regulation of lipogenic and oxidative pathways. J. Biol. Chem. 2005, $280,35983-35991$.

75. Eaton, S.A.; Sethi, J.K. Immunometabolic links between estrogen, adipose tissue and female reproductive metabolism. Biology 2019, 8, 8. [CrossRef] [PubMed]

76. Lovejoy, J.; Champagne, C.; De Jonge, L.; Xie, H.; Smith, S. Increased visceral fat and decreased energy expenditure during the menopausal transition. Int. J. Obes. 2008, 32, 949-958. [CrossRef] [PubMed]

77. Pellegrinelli, V.; Carobbio, S.; Vidal-Puig, A. Adipose tissue plasticity: How fat depots respond differently to pathophysiological cues. Diabetologia 2016, 59, 1075-1088. [CrossRef]

78. Joe, A.W.; Yi, L.; Even, Y.; Vogl, A.W.; Rossi, F.M. Depot-specific differences in adipogenic progenitor abundance and proliferative response to high-fat diet. Stem Cells 2009, 27, 2563-2570. [CrossRef]

79. Lee, M.J.; Fried, S.K. Sex-dependent depot differences in adipose tissue development and function; role of sex steroids. J. Obes. Metab. Syndr. 2017, 26, 172. [CrossRef] [PubMed]

80. Tandon, P.; Wafer, R.; Minchin, J.E. Adipose morphology and metabolic disease. J. Exp. Biol. 2018, 221, jeb164970. [CrossRef] [PubMed]

81. Haczeyni, F.; Bell-Anderson, K.; Farrell, G. Causes and mechanisms of adipocyte enlargement and adipose expansion. Obes. Rev. 2018, 19, 406-420. [CrossRef]

82. Verboven, K.; Wouters, K.; Gaens, K.; Hansen, D.; Bijnen, M.; Wetzels, S.; Stehouwer, C.; Goossens, G.; Schalkwijk, C.; Blaak, E.; et al. Abdominal subcutaneous and visceral adipocyte size, lipolysis and inflammation relate to insulin resistance in male obese humans. Sci. Rep. 2018, 8, 4677. [CrossRef]

83. Weyer, C.; Foley, J.; Bogardus, C.; Tataranni, P.; Pratley, R. Enlarged subcutaneous abdominal adipocyte size, but not obesity itself, predicts type II diabetes independent of insulin resistance. Diabetologia 2000, 43, 1498-1506. [CrossRef]

84. Kim, S.M.; Lun, M.; Wang, M.; Senyo, S.E.; Guillermier, C.; Patwari, P.; Steinhauser, M.L. Loss of white adipose hyperplastic potential is associated with enhanced susceptibility to insulin resistance. Cell Metab. 2014, 20, 1049-1058. [CrossRef]

85. Strissel, K.J.; Stancheva, Z.; Miyoshi, H.; Perfield, J.W.; DeFuria, J.; Jick, Z.; Greenberg, A.S.; Obin, M.S. Adipocyte death, adipose tissue remodeling, and obesity complications. Diabetes 2007, 56, 2910-2918. [CrossRef] [PubMed]

86. Rice, S.P.L.; Zhang, L.; Grennan-Jones, F.; Agarwal, N.; Lewis, M.D.; Rees, D.A.; Ludgate, M. Dehydroepiandrosterone (DHEA) treatment in vitro inhibits adipogenesis in human omental but not subcutaneous adipose tissue. Mol. Cell. Endocrinol. 2010, 320, 51-57. [CrossRef] [PubMed]

87. Gupta, V.; Bhasin, S.; Guo, W.; Singh, R.; Miki, R.; Chauhan, P.; Choong, K.; Tchkonia, T.; Lebrasseur, N.K.; Flanagan, J.N.; et al. Effects of dihydrotestosterone on differentiation and proliferation of human mesenchymal stem cells and preadipocytes. Mol. Cell. Endocrinol. 2008, 296, 32-40. [CrossRef] [PubMed]

88. Mårin, P.; Holmäng, S.; Jönsson, L.; Sjöström, L.; Kvist, H.; Holm, G.; Lindstedt, G.; Björntorp, P. The effects of testosterone treatment on body composition and metabolism in middle-aged obese men. Int. J. Obes. Relat. Metab. Disord. J. Int. Assoc. Study Obes. 1992, 16, 991-997.

89. Allan, C.A.; Strauss, B.J.G.; Burger, H.G.; Forbes, E.A.; McLachlan, R.I. Testosterone therapy prevents gain in visceral adipose tissue and loss of skeletal muscle in nonobese aging men. J. Clin. Endocrinol. Metab. 2008, 93, 139-146. [CrossRef]

90. Münzer, T.; Harman, S.M.; Hees, P.; Shapiro, E.; Christmas, C.; Bellantoni, M.F.; Stevens, T.E.; O'Connor, K.G.; Pabst, K.M.; St. Clair, C.; et al. Effects of GH and/or sex steroid administration on abdominal subcutaneous and visceral fat in healthy aged women and men. J. Clin. Endocrinol. Metab. 2001, 86, 3604-3610. [CrossRef]

91. Björntorp, P. Hormonal control of regional fat distribution. Hum. Reprod. 1997, 12, 21-25. [CrossRef]

92. Rondinone, C.M.; Baker, M.E.; Rodbard, D. Progestins stimulate the differentiation of 3T3-L1 preadipocytes. J. Steroid Biochem. Mol. Biol. 1992, 42, 795-802. [CrossRef]

93. Hauner, H.; Schmid, P.; Pfeiffer, E.F. Glucocorticoids and insulin promote the differentiation of human adipocyte precursor cells into fat cells. J. Clin. Endocrinol. Metab. 1987, 64, 832-835. [CrossRef]

94. Mundi, M.S.; Koutsari, C.; Jensen, M.D. Effects of increased free fatty acid availability on adipose tissue fatty acid storage in men. J. Clin. Endocrinol. Metab. 2014, 99, E2635-E2642. [CrossRef]

95. Wu, Y.; Lee, M.J.; Ido, Y.; Fried, S.K. High-fat diet-induced obesity regulates MMP3 to modulate depot-and sex-dependent adipose expansion in C57BL/6J mice. Am. J. Physiol. Endocrinol. Metab. 2017, 312, E58-E71. [CrossRef] [PubMed]

96. Lee, H.K.; Lee, J.K.; Cho, B. The role of androgen in the adipose tissue of males. World J. Men's Health 2013, 31, 136. [CrossRef] [PubMed]

97. XU, X.; PERGOLA, G.D.; BJÖRNTORP, P. The effects of androgens on the regulation of lipolysis in adipose precursor cells. Endocrinology 1990, 126, 1229-1234. [CrossRef]

98. Karbowska, J.; Kochan, Z. Fat-reducing effects of dehydroepiandrosterone involve upregulation of ATGL and HSL expression, and stimulation of lipolysis in adipose tissue. Steroids 2012, 77, 1359-1365. [CrossRef]

99. Rebuffe-Scrive, M.; Mårin, P.; Björntorp, P. Effect of testosterone on abdominal adipose tissue in men. Int. J. Obes. 1991, 15, 791-795. 
100. Pecquery, R.; Leneveu, M.C.; Giudicelli, Y. Influence of androgenic status on the $\alpha 2 / \beta$-adrenergic control of lipolysis in white fat cells: Predominant $\alpha 2$-antilipolytic response in testosterone-treated-castrated hamsters. Endocrinology 1988, 122, $2590-2596$. [CrossRef]

101. Xu, X.; Pergola, G.D.; Björntorp, P. Testosterone increases lipolysis and the number of $\beta$-adrenoceptors in male rat adipocytes. Endocrinology 1991, 128, 379-382. [CrossRef]

102. Dicker, A.; Ryden, M.; Näslund, E.; Muehlen, I.E.; Wiren, M.; Lafontan, M.; Arner, P. Effect of testosterone on lipolysis in human pre-adipocytes from different fat depots. Diabetologia 2004, 47, 420-428. [CrossRef]

103. Anderson, L.; McTernan, P.; Harte, A.; Barnett, A.; Kumar, S. The regulation of HSL and LPL expression by DHT and flutamide in human subcutaneous adipose tissue. Diabetes Obes. Metab. 2002, 4, 209-213. [CrossRef]

104. Rydén, M.; Jocken, J.; Van Harmelen, V.; Dicker, A.; Hoffstedt, J.; Wirén, M.; Blomqvist, L.; Mairal, A.; Langin, D.; Blaak, E.; et al. Comparative studies of the role of hormone-sensitive lipase and adipose triglyceride lipase in human fat cell lipolysis. Am. J. Physiol. Endocrinol. Metab. 2007, 292, E1847-E1855. [CrossRef]

105. Pedersen, S.B.; Kristensen, K.; Hermann, P.A.; Katzenellenbogen, J.A.; Richelsen, B. Estrogen controls lipolysis by up-regulating $\alpha 2 \mathrm{~A}$-adrenergic receptors directly in human adipose tissue through the estrogen receptor $\alpha$. Implications for the female fat distribution. J. Clin. Endocrinol. Metab. 2004, 89, 1869-1878. [CrossRef]

106. Santosa, S.; Bonnes, S.L.; Jensen, M.D. Acute female hypogonadism alters adipose tissue fatty acid storage factors and chylomicronemia. J. Clin. Endocrinol. Metab. 2016, 101, 2089-2098. [CrossRef]

107. Lundholm, L.; Zang, H.; Hirschberg, A.L.; Gustafsson, J.Å.; Arner, P.; Dahlman-Wright, K. Key lipogenic gene expression can be decreased by estrogen in human adipose tissue. Fertil. Steril. 2008, 90, 44-48. [CrossRef] [PubMed]

108. Stirone, C.; Boroujerdi, A.; Duckles, S.P.; Krause, D.N. Estrogen receptor activation of phosphoinositide-3 kinase, akt, and nitric oxide signaling in cerebral blood vessels: Rapid and long-term effects. Mol. Pharmacol. 2005, 67, 105-113. [CrossRef] [PubMed]

109. Mendes, A.M.; Madon, R.; Flint, D. Effects of cortisol and progesterone on insulin binding and lipogenesis in adipocytes from normal and diabetic rats. J. Endocrinol. 1985, 106, 225-231. [CrossRef] [PubMed]

110. Stelmanska, E.; Swierczynski, J. Up-regulation of lipogenic enzyme genes expression in inguinal white adipose tissue of female rats by progesterone. J. Steroid Biochem. Mol. Biol. 2013, 134, 37-44. [CrossRef]

111. Stelmanska, E.; Szrok, S.; Swierczynski, J. Progesterone-induced down-regulation of hormone sensitive lipase (Lipe) and up-regulation of G0/G1 switch 2 (G0s2) genes expression in inguinal adipose tissue of female rats is reflected by diminished rate of lipolysis. J. Steroid Biochem. Mol. Biol. 2015, 147, 31-39. [CrossRef]

112. Pedersen, S.B.; Kristensen, K.; Richelsen, B. Anti-glucocorticoid effects of progesterone in vivo on rat adipose tissue metabolism. Steroids 2003, 68, 543-550. [CrossRef]

113. Pedersen, S.B.; Børglum, J.D.; Møller-Pedersen, T.; Richelsen, B. Characterization of nuclear corticosteroid receptors in rat adipocytes. Regional variations and modulatory effects of hormones. Biochim. Biophys. Acta BBA Mol. Cell Res. 1992, 1134, 303-308. [CrossRef]

114. Sutter-Dub, M.T.; Sfaxi, A.; Strozza, P. Glucose metabolism in the female rat adipocyte: Lipid synthesis from glucose during pregnancy and progesterone treatment. J. Endocrinol. 1983, 97, 207-212. [CrossRef]

115. Sutter-Dub, M.T.; Dazey, B.; Hamdan, E.; Vergnaud, M.T. Progesterone and insulin-resistance: Studies of progesterone action on glucose transport, lipogenesis and lipolysis in isolated fat cells of the female rat. J. Endocrinol. 1981, 88, 455-462. [CrossRef] [PubMed]

116. Shirling, D.; Ashby, J.; Baird, J. Effect of progesterone on lipid metabolism in the intact rat. J. Endocrinol. 1981, 90, 285-294. [CrossRef] [PubMed]

117. Kautzky-Willer, A.; Brazzale, A.R.; Moro, E.; Vrbíková, J.; Bendlova, B.; Sbrignadello, S.; Tura, A.; Pacini, G. Influence of increasing BMI on insulin sensitivity and secretion in normotolerant men and women of a wide age span. Obesity 2012, 20, 1966-1973. [CrossRef] [PubMed]

118. Tramunt, B.; Smati, S.; Grandgeorge, N.; Lenfant, F.; Arnal, J.F.; Montagner, A.; Gourdy, P. Sex differences in metabolic regulation and diabetes susceptibility. Diabetologia 2020, 63, 453-461. [CrossRef] [PubMed]

119. Varlamov, O.; Bethea, C.L.; Roberts, C.T., Jr. Sex-specific differences in lipid and glucose metabolism. Front. Endocrinol. 2015, 5, 241. [CrossRef] [PubMed]

120. Muraki, K.; Okuya, S.; Tanizawa, Y. Estrogen receptor $\alpha$ regulates insulin sensitivity through IRS-1 tyrosine phosphorylation in mature 3T3-L1 adipocytes. Endocr. J. 2006, 53, 841-851. [CrossRef]

121. Kim, J.Y.; Jo, K.J.; Kim, B.J.; Baik, H.W.; Lee, S.K. $17 \beta$-estradiol induces an interaction between adenosine monophosphate-activated protein kinase and the insulin signaling pathway in 3T3-L1 adipocytes. Int. J. Mol. Med. 2012, 30, 979-985. [CrossRef]

122. Dhindsa, S.; Ghanim, H.; Batra, M.; Dandona, P. Hypogonadotropic hypogonadism in men with diabesity. Diabetes Care 2018, 41, 1516-1525. [CrossRef]

123. Sanchez-Garrido, M.A.; Tena-Sempere, M. Metabolic dysfunction in polycystic ovary syndrome: Pathogenic role of androgen excess and potential therapeutic strategies. Mol. Metab. 2020, 35, 100937. [CrossRef]

124. Corbould, A. Chronic testosterone treatment induces selective insulin resistance in subcutaneous adipocytes of women. J. Endocrinol. 2007, 192, 585-594. [CrossRef]

125. Upreti, R.; Hughes, K.A.; Livingstone, D.E.; Gray, C.D.; Minns, F.C.; Macfarlane, D.P.; Marshall, I.; Stewart, L.H.; Walker, B.R.; Andrew, R. $5 \alpha$-reductase type 1 modulates insulin sensitivity in men. J. Clin. Endocrinol. Metab. 2014, 99, E1397-E1406. [CrossRef] 
126. Livingstone, D.E.; Barat, P.; Di Rollo, E.M.; Rees, G.A.; Weldin, B.A.; Rog-Zielinska, E.A.; MacFarlane, D.P.; Walker, B.R.; Andrew, R. $5 \alpha$-Reductase type 1 deficiency or inhibition predisposes to insulin resistance, hepatic steatosis, and liver fibrosis in rodents. Diabetes 2015, 64, 447-458. [CrossRef] [PubMed]

127. Andrisse, S.; Billings, K.; Xue, P.; Wu, S. Insulin signaling displayed a differential tissue-specific response to low-dose dihydrotestosterone in female mice. Am. J. Physiol. Endocrinol. Metab. 2018, 314, E353-E365. [CrossRef]

128. Dillon, J.S.; Yaney, G.C.; Zhou, Y.; Voilley, N.; Bowen, S.; Chipkin, S.; Bliss, C.R.; Schultz, V.; Schuit, F.C.; Prentki, M.; et al. Dehydroepiandrosterone sulfate and beta-cell function: Enhanced glucose-induced insulin secretion and altered gene expression in rodent pancreatic beta-cells. Diabetes 2000, 49, 2012-2020. [CrossRef] [PubMed]

129. Aoki, K.; Terauchi, Y. Effect of dehydroepiandrosterone (DHEA) on diabetes mellitus and obesity. Vitam. Horm. 2018, 108, 355-365. [PubMed]

130. Apostolova, G.; Schweizer, R.A.; Balazs, Z.; Kostadinova, R.M.; Odermatt, A. Dehydroepiandrosterone inhibits the amplification of glucocorticoid action in adipose tissue. Am. J. Physiol. Endocrinol. Metab. 2005, 288, E957-E964. [CrossRef]

131. McNelis, J.C.; Manolopoulos, K.N.; Gathercole, L.L.; Bujalska, I.J.; Stewart, P.M.; Tomlinson, J.W.; Arlt, W. Dehydroepiandrosterone exerts antiglucocorticoid action on human preadipocyte proliferation, differentiation, and glucose uptake. Am. J. Physiol. Endocrinol. Metab. 2013, 305, E1134-E1144. [CrossRef]

132. Tagawa, N.; Minamitani, E.; Yamaguchi, Y.; Kobayashi, Y. Alternative mechanism for anti-obesity effect of dehydroepiandrosterone: Possible contribution of $11 \beta$-hydroxysteroid dehydrogenase type 1 inhibition in rodent adipose tissue. Steroids 2011, 76, 1546-1553. [CrossRef] [PubMed]

133. Burhans, M.S.; Hagman, D.K.; Kuzma, J.N.; Schmidt, K.A.; Kratz, M. Contribution of adipose tissue inflammation to the development of type 2 diabetes mellitus. Compr. Physiol. 2011, 9, 1-58.

134. Zatterale, F.; Longo, M.; Naderi, J.; Raciti, G.A.; Desiderio, A.; Miele, C.; Beguinot, F. Chronic adipose tissue inflammation linking obesity to insulin resistance and type 2 diabetes. Front. Physiol. 2020, 10, 1607. [CrossRef]

135. Hardy, O.T.; Czech, M.P.; Corvera, S. What Causes the Insulin Resistance Underlying Obesity? Curr. Opin. Endocrinol. Diabetes Obes. 2012, 19, 81-87. [CrossRef]

136. Atawia, R.T.; Bunch, K.L.; Toque, H.A.; Caldwell, R.B.; Caldwell, R.W. Mechanisms of obesity-induced metabolic and vascular dysfunctions. Front. Biosci. (Landmark Ed.) 2019, 24, 890-934. [PubMed]

137. Maiorino, M.; Bellastella, G.; Giugliano, D.; Esposito, K. From inflammation to sexual dysfunctions: A journey through diabetes, obesity, and metabolic syndrome. J. Endocrinol. Investig. 2018, 41, 1249-1258. [CrossRef]

138. Rak, A.; Mellouk, N.; Froment, P.; Dupont, J. Adiponectin and resistin: Potential metabolic signals affecting hypothalamo-pituitary gonadal axis in females and males of different species. Reproduction 2017, 153, R215-R226. [CrossRef] [PubMed]

139. Jenks, M.Z.; Fairfield, H.E.; Johnson, E.C.; Morrison, R.F.; Muday, G.K. Sex steroid hormones regulate leptin transcript accumulation and protein secretion in 3T3-L1 cells. Sci. Rep. 2017, 7, 8232. [CrossRef] [PubMed]

140. Casabiell, X.; Pineiro, V.; Peino, R.; Lage, M.; Camina, J.; Gallego, R.; Vallejo, L.G.; Dieguez, C.; Casanueva, F.F. Gender differences in both spontaneous and stimulated leptin secretion by human omental adipose tissue in vitro: Dexamethasone and estradiol stimulate leptin release in women, but not in men. J. Clin. Endocrinol. Metab. 1998, 83, 2149-2155. [CrossRef]

141. Machinal, F.; Dieudonne, M.N.; Leneveu, M.C.; Pecquery, R.; Giudicelli, Y. In vivo and in vitro ob gene expression and leptin secretion in rat adipocytes: Evidence for a regional specific regulation by sex steroid hormones. Endocrinology 1999, 140, 1567-1574 [CrossRef] [PubMed]

142. Wabitsch, M.; Blum, W.F.; Muche, R.; Braun, M.; Hube, F.; Rascher, W.; Heinze, E.; Teller, W.; Hauner, H. Contribution of androgens to the gender difference in leptin production in obese children and adolescents. J. Clin. Investig. 1997, 100, 808-813. [CrossRef]

143. Yamauchi, T.; Iwabu, M.; Okada-Iwabu, M.; Kadowaki, T. Adiponectin receptors: A review of their structure, function and how they work. Best Pract. Res. Clin. Endocrinol. Metab. 2014, 28, 15-23. [CrossRef]

144. Nishizawa, H.; Shimomura, I.; Kishida, K.; Maeda, N.; Kuriyama, H.; Nagaretani, H.; Matsuda, M.; Kondo, H.; Furuyama, N.; Kihara, S.; et al. Androgens decrease plasma adiponectin, an insulin-sensitizing adipocyte-derived protein. Diabetes 2002, 51, 2734-2741. [CrossRef]

145. Xu, A.; Chan, K.W.; Hoo, R.L.; Wang, Y.; Tan, K.C.; Zhang, J.; Chen, B.; Lam, M.C.; Tse, C.; Cooper, G.J.; et al. Testosterone selectively reduces the high molecular weight form of adiponectin by inhibiting its secretion from adipocytes. J. Biol. Chem. 2005, 280, 18073-18080. [CrossRef] [PubMed]

146. Mannerås-Holm, L.; Leonhardt, H.; Kullberg, J.; Jennische, E.; Odén, A.; Holm, G.; Hellström, M.; Lönn, L.; Olivecrona, G.; Stener-Victorin, E.; et al. Adipose tissue has aberrant morphology and function in PCOS: Enlarged adipocytes and low serum adiponectin, but not circulating sex steroids, are strongly associated with insulin resistance. J. Clin. Endocrinol. Metab. 2011, 96, E304-E311. [CrossRef] [PubMed]

147. Estienne, A.; Bongrani, A.; Reverchon, M.; Ramé, C.; Ducluzeau, P.H.; Froment, P.; Dupont, J. Involvement of novel adipokines, chemerin, visfatin, resistin and apelin in reproductive functions in normal and pathological conditions in humans and animal models. Int. J. Mol. Sci. 2019, 20, 4431. [CrossRef]

148. Steppan, C.M.; Bailey, S.T.; Bhat, S.; Brown, E.J.; Banerjee, R.R.; Wright, C.M.; Patel, H.R.; Ahima, R.S.; Lazar, M.A. The hormone resistin links obesity to diabetes. Nature 2001, 409, 307-312. [CrossRef] [PubMed] 
149. Martos-Moreno, G.A.; Barrios, V.; Argente, J. Normative data for adiponectin, resistin, interleukin 6, and leptin/receptor ratio in a healthy Spanish pediatric population: Relationship with sex steroids. Eur. J. Endocrinol. 2006, 155, 429-434. [CrossRef] [PubMed]

150. Munir, I.; Yen, H.W.; Baruth, T.; Tarkowski, R.; Azziz, R.; Magoffin, D.A.; Jakimiuk, A.J. Resistin stimulation of $17 \alpha$-hydroxylase activity in ovarian theca cells in vitro: Relevance to polycystic ovary syndrome. J. Clin. Endocrinol. Metab. 2005, 90, $4852-4857$. [CrossRef] [PubMed]

151. Seow, K.M.; Juan, C.C.; Ho, L.T.; Hsu, Y.P.; Lin, Y.H.; Huang, L.W.; Hwang, J.L. Adipocyte resistin mRNA levels are downregulated by laparoscopic ovarian electrocautery in both obese and lean women with polycystic ovary syndrome. Hum. Reprod. 2007, 22, 1100-1106. [CrossRef] [PubMed]

152. Seow, K.M.; Juan, C.C.; Wu, L.Y.; Hsu, Y.P.; Yang, W.M.; Tsai, Y.L.; Hwang, J.L.; Ho, L.T. Serum and adipocyte resistin in polycystic ovary syndrome with insulin resistance. Hum. Reprod. 2004, 19, 48-53. [CrossRef]

153. Svendsen, P.F.; Christiansen, M.; Hedley, P.L.; Nilas, L.; Pedersen, S.B.; Madsbad, S. Adipose expression of adipocytokines in women with polycystic ovary syndrome. Fertil. Steril. 2012, 98, 235-241. [CrossRef]

154. Panidis, D.; Koliakos, G.; Kourtis, A.; Farmakiotis, D.; Mouslech, T.; Rousso, D. Serum resistin levels in women with polycystic ovary syndrome. Fertil. Steril. 2004, 81, 361-366. [CrossRef]

155. Kapoor, D.; Clarke, S.; Stanworth, R.; Channer, K.; Jones, T. The effect of testosterone replacement therapy on adipocytokines and C-reactive protein in hypogonadal men with type 2 diabetes. Eur. J. Endocrinol. 2007, 156, 595-602. [CrossRef] [PubMed]

156. Varghese, M.; Griffin, C.; Singer, K. The role of sex and sex hormones in regulating obesity-induced inflammation. Sex Gend. Factors Affect. Metab. Homeost. Diabetes Obes. 2017, 1043, 65-86.

157. Rubinow, K.B.; Chao, J.H.; Hagman, D.; Kratz, M.; Van Yserloo, B.; Gaikwad, N.W.; Amory, J.K.; Page, S.T. Circulating sex steroids coregulate adipose tissue immune cell populations in healthy men. Am. J. Physiol. Endocrinol. Metab. 2017, 313, E528-E539. [CrossRef] [PubMed]

158. Rubinow, K.B. An intracrine view of sex steroids, immunity, and metabolic regulation. Mol. Metab. 2018, 15, 92-103. [CrossRef] [PubMed]

159. Henze, L.; Schwinge, D.; Schramm, C. The Effects of Androgens on T Cells: Clues to Female Predominance in Autoimmune Liver Diseases? Front. Immunol. 2020, 11, 1567. [CrossRef] [PubMed]

160. Oertelt-Prigione, S. The influence of sex and gender on the immune response. Autoimmun. Rev. 2012, 11, A479-A485. [CrossRef]

161. Trigunaite, A.; Dimo, J.; Jørgensen, T.N. Suppressive effects of androgens on the immune system. Cell. Immunol. 2015, 294, 87-94. [CrossRef]

162. Ghisletti, S.; Meda, C.; Maggi, A.; Vegeto, E. $17 \beta$-estradiol inhibits inflammatory gene expression by controlling NF- $\kappa$ B intracellular localization. Mol. Cell. Biol. 2005, 25, 2957-2968. [CrossRef]

163. Stubbins, R.E.; Najjar, K.; Holcomb, V.B.; Hong, J.; Nú nez, N.P. Oestrogen alters adipocyte biology and protects female mice from adipocyte inflammation and insulin resistance. Diabetes Obes. Metab. 2012, 14, 58-66. [CrossRef]

164. Calippe, B.; Douin-Echinard, V.; Laffargue, M.; Laurell, H.; Rana-Poussine, V.; Pipy, B.; Guéry, J.C.; Bayard, F.; Arnal, J.F.; Gourdy, P. Chronic estradiol administration in vivo promotes the proinflammatory response of macrophages to TLR4 activation: Involvement of the phosphatidylinositol 3-kinase pathway. J. Immunol. 2008, 180, 7980-7988. [CrossRef]

165. Calippe, B.; Douin-Echinard, V.; Delpy, L.; Laffargue, M.; Lélu, K.; Krust, A.; Pipy, B.; Bayard, F.; Arnal, J.F.; Guéry, J.C.; et al. $17 \beta$-estradiol promotes TLR4-triggered proinflammatory mediator production through direct estrogen receptor $\alpha$ signaling in macrophages in vivo. J. Immunol. 2010, 185, 1169-1176. [CrossRef] [PubMed]

166. Mu, P.W.; Jiang, P.; Wang, M.M.; Chen, Y.M.; Zheng, S.H.; Tan, Z.; Jiang, W.; Zeng, L.Y.; Wang, T.H. Oestrogen exerts antiinflammation via p38 MAPK/NF- $\kappa$ B cascade in adipocytes. Obes. Res. Clin. Pract. 2016, 10, 633-641. [CrossRef] [PubMed]

167. Biswas, D.K.; Singh, S.; Shi, Q.; Pardee, A.B.; Iglehart, J.D. Crossroads of estrogen receptor and NF- $\kappa$ B signaling. Science's STKE 2005, 2005, pe27. [PubMed]

168. Straub, R.H. The complex role of estrogens in inflammation. Endocr. Rev. 2007, 28, 521-574. [CrossRef] [PubMed]

169. Traish, A.; Bolanos, J.; Nair, S.; Saad, F.; Morgentaler, A. Do androgens modulate the pathophysiological pathways of inflammation? Appraising the contemporary evidence. J. Clin. Med. 2018, 7, 549. [CrossRef] [PubMed]

170. Malkin, C.J.; Pugh, P.J.; Jones, R.D.; Kapoor, D.; Channer, K.S.; Jones, T.H. The effect of testosterone replacement on endogenous inflammatory cytokines and lipid profiles in hypogonadal men. J. Clin. Endocrinol. Metab. 2004, 89, 3313-3318. [CrossRef]

171. Asai, K.; Hiki, N.; Mimura, Y.; Ogawa, T.; Unou, K.; Kaminishi, M. Gender differences in cytokine secretion by human peripheral blood mononuclear cells: Role of estrogen in modulating LPS-induced cytokine secretion in an ex vivo septic model. Shock (Augusta GA) 2001, 16, 340-343. [CrossRef]

172. Torcia, M.G.; Nencioni, L.; Clemente, A.M.; Civitelli, L.; Celestino, I.; Limongi, D.; Fadigati, G.; Perissi, E.; Cozzolino, F.; Garaci, E.; et al. Sex differences in the response to viral infections: TLR8 and TLR9 ligand stimulation induce higher IL10 production in males. PLoS ONE 2012, 7, e39853.

173. Channappanavar, R.; Fett, C.; Mack, M.; Ten Eyck, P.P.; Meyerholz, D.K.; Perlman, S. Sex-based differences in susceptibility to severe acute respiratory syndrome coronavirus infection. J. Immunol. 2017, 198, 4046-4053. [CrossRef]

174. Takahashi, T.; Ellingson, M.K.; Wong, P.; Israelow, B.; Lucas, C.; Klein, J.; Silva, J.; Mao, T.; Oh, J.E.; Tokuyama, M.; et al. Sex differences in immune responses that underlie COVID-19 disease outcomes. Nature 2020, 588, 315-320. [CrossRef]

175. Al-Lami, R.A.; Urban, R.J.; Volpi, E.; Algburi, A.M.; Baillargeon, J. Sex hormones and novel corona virus infectious disease (COVID-19). Mayo Clin. Proc. 2020, 95, 1710-1714. [CrossRef] [PubMed] 
176. Carbrey, J.M.; Agre, P. Discovery of the aquaporins and development of the field. In Aquaporins. Handbook of Experimental Pharmacology; Springer: Berlin/Heidelberg, Germany, 2009; pp. 3-28.

177. Gomes, D.; Agasse, A.; Thiébaud, P.; Delrot, S.; Gerós, H.; Chaumont, F. Aquaporins are multifunctional water and solute transporters highly divergent in living organisms. Biochim. Biophys. Acta BBA Biomembr. 2009, 1788, 1213-1228. [CrossRef]

178. Benga, G. On the definition, nomenclature and classification of water channel proteins (aquaporins and relatives). Mol. Asp. Med. 2012, 33, 514-517. [CrossRef]

179. Jahn, T.P.; Møller, A.L.; Zeuthen, T.; Holm, L.M.; Klærke, D.A.; Mohsin, B.; Kühlbrandt, W.; Schjoerring, J.K. Aquaporin homologues in plants and mammals transport ammonia. FEBS Lett. 2004, 574, 31-36. [CrossRef] [PubMed]

180. Litman, T.; Søgaard, R.; Zeuthen, T. Ammonia and urea permeability of mammalian aquaporins. In Aquaporins. Handbook of Experimental Pharmacology; Springer: Berlin/Heidelberg, Germany, 2009; pp. 327-358.

181. Bertolotti, M.; Bestetti, S.; García-Manteiga, J.M.; Medrano-Fernandez, I.; Dal Mas, A.; Malosio, M.L.; Sitia, R. Tyrosine kinase signal modulation: A matter of $\mathrm{H}_{2} \mathrm{O}_{2}$ membrane permeability? Antioxid. Redox Signal. 2013, 19, 1447-1451. [CrossRef] [PubMed]

182. Miller, E.W.; Dickinson, B.C.; Chang, C.J. Aquaporin-3 mediates hydrogen peroxide uptake to regulate downstream intracellular signaling. Proc. Natl. Acad. Sci. USA 2010, 107, 15681-15686. [CrossRef] [PubMed]

183. Watanabe, S.; Moniaga, C.S.; Nielsen, S.; Hara-Chikuma, M. Aquaporin-9 facilitates membrane transport of hydrogen peroxide in mammalian cells. Biochem. Biophys. Res. Commun. 2016, 471, 191-197. [CrossRef]

184. Bestetti, S.; Galli, M.; Sorrentino, I.; Pinton, P.; Rimessi, A.; Sitia, R.; Medra no-Fernandez, I. Human aquaporin-11 guarantees efficient transport of $\mathrm{H} 2 \mathrm{O} 2$ across the endoplasmic reticulum membrane. Redox Biol. 2020, 28, 101326. [CrossRef]

185. Vilchis-Landeros, M.; Guinzberg, R.; Riveros-Rosas, H.; Villalobos-Molina, R.; Pi na, E. Aquaporin 8 is involved in H2O2mediated differential regulation of metabolic signaling by $\alpha 1$-and $\beta$-adrenoceptors in hepatocytes. FEBS Lett. 2020, 594, 1564-1576. [CrossRef]

186. Rodrigues, C.; Pimp ao, C.; Mósca, A.F.; Coxixo, A.S.; Lopes, D.; da Silva, I.V.; Pedersen, P.A.; Antunes, F.; Soveral, G. Human aquaporin-5 facilitates hydrogen peroxide permeation affecting adaption to oxidative stress and cancer cell migration. Cancers 2019, 11, 932. [CrossRef]

187. Rodríguez, A.; Catalán, V.; Gómez-Ambrosi, J.; Frühbeck, G. Aquaglyceroporins serve as metabolic gateways in adiposity and insulin resistance control. Cell Cycle 2011, 10, 1548-1556. [CrossRef] [PubMed]

188. Lebeck, J. Metabolic impact of the glycerol channels AQP7 and AQP9 in adipose tissue and liver. J. Mol. Endocrinol. 2014, 52, R165-R178. [CrossRef] [PubMed]

189. Lafontan, M. Adipose tissue and adipocyte dysregulation. Diabetes Metab. 2014, 40, 16-28. [CrossRef] [PubMed]

190. Frühbeck, G. Aquaporin enters the picture. Nature 2005, 438, 436-437. [CrossRef] [PubMed]

191. Hibuse, T.; Maeda, N.; Funahashi, T.; Yamamoto, K.; Nagasawa, A.; Mizunoya, W.; Kishida, K.; Inoue, K.; Kuriyama, H.; Nakamura, T.; et al. Aquaporin 7 deficiency is associated with development of obesity through activation of adipose glycerol kinase. Proc. Natl. Acad. Sci. USA 2005, 102, 10993-10998. [CrossRef]

192. MacDougald, O.A.; Burant, C.F. Obesity and metabolic perturbations after loss of aquaporin 7 , the adipose glycerol transporter. Proc. Natl. Acad. Sci. USA 2005, 102, 10759-10760. [CrossRef]

193. Ceperuelo-Mallafré, V.; Miranda, M.; Chacón, M.; Vilarrasa, N.; Megia, A.; Gutiérrez, C.; Fernandez-Real, J.; Gomez, J.; Caubet, E.; Fruhbeck, G.; et al. Adipose tissue expression of the glycerol channel aquaporin-7 gene is altered in severe obesity but not in type 2 diabetes. J. Clin. Endocrinol. Metab. 2007, 92, 3640-3645. [CrossRef]

194. da Silva, I.V.; Soveral, G. Aquaporins in obesity. In Aquaporins. Advances in Experimental Medicine and Biology; Springer: Dordrecht, Germany, 2017; pp. 227-238.

195. Lebeck, J.; Østergård, T.; Rojek, A.; Füchtbauer, E.M.; Lund, S.; Nielsen, S.; Praetorius, J. Gender-specific effect of physical training on AQP7 protein expression in human adipose tissue. Acta Diabetol. 2012, 49, 215-226. [CrossRef]

196. Rodríguez, A.; Marinelli, R.A.; Tesse, A.; Frühbeck, G.; Calamita, G. Sexual dimorphism of adipose and hepatic aquaglyceroporins in health and metabolic disorders. Front. Endocrinol. 2015, 6, 171. [CrossRef]

197. da Silva, I.V.; Rodrigues, J.S.; Rebelo, I.; Miranda, J.P.; Soveral, G. Revisiting the metabolic syndrome: The emerging role of aquaglyceroporins. Cell. Mol. Life Sci. 2018, 75, 1973-1988. [CrossRef]

198. Shen, F.X.; Gu, X.; Pan, W.; Li, W.P.; Li, W.; Ye, J.; Yang, L.J.; Gu, X.J.; Ni, L.S. Over-expression of AQP7 contributes to improve insulin resistance in adipocytes. Exp. Cell Res. 2012, 318, 2377-2384. [CrossRef]

199. Kishida, K.; Shimomura, I.; Nishizawa, H.; Maeda, N.; Kuriyama, H.; Kondo, H.; Matsuda, M.; Nagaretani, H.; Ouchi, N.; Hotta, K.; et al. Enhancement of the aquaporin adipose gene expression by a peroxisome proliferator-activated receptor $\gamma$. J. Biol. Chem. 2001, 276, 48572-48579. [CrossRef] [PubMed]

200. Kondo, H.; Shimomura, I.; Kishida, K.; Kuriyama, H.; Makino, Y.; Nishizawa, H.; Matsuda, M.; Maeda, N.; Nagaretani, H.; Kihara, S.; et al. Human aquaporin adipose (AQPap) gene: Genomic structure, promoter analysis and functional mutation. Eur. J. Biochem. 2002, 269, 1814-1826. [CrossRef] [PubMed]

201. Lindgren, C.; Mahtani, M.; Widen, E.; McCarthy, M.; Daly, M.; Kirby, A.; Reeve, M.; Kruglyak, L.; Parker, A.; Meyer, J.; et al. Genomewide search for type 2 diabetes mellitus susceptibility loci in Finnish families: The Botnia study. Am. J. Hum. Genet. 2002, 70, 509-516. [CrossRef] [PubMed] 
202. Loos, R.J.; Katzmarzyk, P.T.; Rao, D.; Rice, T.; Leon, A.S.; Skinner, J.S.; Wilmore, J.H.; Rankinen, T.; Bouchard, C. Genome-wide linkage scan for the metabolic syndrome in the HERITAGE Family Study. J. Clin. Endocrinol. Metab. 2003, 88, 5935-5943. [CrossRef] [PubMed]

203. da Silva, I.V.; Soveral, G. Aquaporins in Immune Cells and Inflammation: New Targets for Drug Development. Int. J. Mol. Sci. 2021, 22, 1845. [CrossRef] [PubMed]

204. da Silva, I.V.; Cardoso, C.; Martínez-Banaclocha, H.; Casini, A.; Pelegrín, P.; Soveral, G. Aquaporin-3 is involved in NLRP3inflammasome activation contributing to the setting of inflammatory response. Cell. Mol. Life Sci. 2020, 78, 3073-3085. [CrossRef] [PubMed]

205. Huang, H.F.; He, R.H.; Sun, C.C.; Zhang, Y.; Meng, Q.X.; Ma, Y.Y. Function of aquaporins in female and male reproductive systems. Hum. Reprod. Update 2006, 12, 785-795. [CrossRef]

206. Carrageta, D.F.; Bernardino, R.L.; Soveral, G.; Calamita, G.; Alves, M.G.; Oliveira, P.F. Aquaporins and male (in) fertility: Expression and role throughout the male reproductive tract. Arch. Biochem. Biophys. 2020, 679, 108222. [CrossRef]

207. Zhu, C.; Jiang, Z.; Bazer, F.W.; Johnson, G.A.; Burghardt, R.C.; Wu, G. Aquaporins in the female reproductive system of mammals. Front. Biosci. (Landmark Ed.) 2015, 20, 838-871.

208. Wawrzkiewicz-Jałowiecka, A.; Kowalczyk, K.; Pluta, D.; Blukacz, Ł.; Madej, P. The role of aquaporins in polycystic ovary syndrome-A way towards a novel drug target in PCOS. Med. Hypotheses 2017, 102, 23-27. [CrossRef] [PubMed]

209. Oliveira, C.A.; Carnes, K.; França, L.R.; Hermo, L.; Hess, R.A. Aquaporin-1 and- 9 are differentially regulated by oestrogen in the efferent ductule epithelium and initial segment of the epididymis. Biol. Cell 2005, 97, 385-395. [CrossRef] [PubMed]

210. Li, X.; Yu, H.; Koide, S. Regulation of water channel gene (AQP-CHIP) expression by estradiol and anordiol in rat uterus. Acta Pharm. Sin 1997, 32, 586-592.

211. Zhou, Q.; Clarke, L.; Nie, R.; Carnes, K.; Lai, L.W.; Lien, Y.H.H.; Verkman, A.; Lubahn, D.; Fisher, J.S.; Katzenellenbogen, B.S.; et al Estrogen action and male fertility: Roles of the sodium/hydrogen exchanger-3 and fluid reabsorption in reproductive tract function. Proc. Natl. Acad. Sci. USA 2001, 98, 14132-14137. [CrossRef] [PubMed]

212. Weiss, J.; Bernhardt, M.L.; Laronda, M.M.; Hurley, L.A.; Glidewell-Kenney, C.; Pillai, S.; Tong, M.; Korach, K.S.; Jameson, J.L. Estrogen actions in the male reproductive system involve estrogen response element-independent pathways. Endocrinology 2008, 149, 6198-6206. [CrossRef]

213. Pastor-Soler, N.M.; Fisher, J.S.; Sharpe, R.; Hill, E.; Van Hoek, A.; Brown, D.; Breton, S. Aquaporin 9 expression in the developing rat epididymis is modulated by steroid hormones. Reprod. (Camb. Engl.) 2010, 139, 613. [CrossRef]

214. Bernardino, R.L.; Carrageta, D.F.; Silva, A.M.; Calamita, G.; Alves, M.G.; Soveral, G.; Oliveira, P.F. Estrogen modulates glycerol permeability in sertoli cells through downregulation of aquaporin-9. Cells 2018, 7, 153. [CrossRef]

215. Salleh, N.; Mokhtar, H.M.; Kassim, N.M.; Giribabu, N. Testosterone induces increase in aquaporin (AQP)-1, 5, and 7 expressions in the uteri of ovariectomized rats. J. Membr. Biol. 2015, 248, 1097-1105. [CrossRef]

216. Pastor-Soler, N.; Isnard-Bagnis, C.; Herak-Kramberger, C.; Sabolic, I.; Van Hoek, A.; Brown, D.; Breton, S. Expression of aquaporin 9 in the adult rat epididymal epithelium is modulated by androgens. Biol. Reprod. 2002, 66, 1716-1722. [CrossRef]

217. Ramli, N.S.K.; Giribabu, N.; Karim, K.; Salleh, N. Hormonal control of vas deferens fluid volume and aquaporin expression in rats. J. Mol. Histol. 2019, 50, 21-34. [CrossRef]

218. Tian, J.; Xia, J.; Jiang, J.; Jiang, R.; He, Y.; Lin, H. Effect of androgen deprivation on the expression of aquaporins in rat prostate and seminal vesicles. Andrologia 2016, 48, 268-276. [CrossRef] [PubMed]

219. Loh, S.Y.; Giribabu, N.; Salleh, N. Effects of gonadectomy and testosterone treatment on aquaporin expression in the kidney of normotensive and hypertensive rats. Exp. Biol. Med. 2017, 242, 1376-1386. [CrossRef] [PubMed]

220. Gu, F.; Hata, R.; Toku, K.; Yang, L.; Ma, Y.J.; Maeda, N.; Sakanaka, M.; Tanaka, J. Testosterone up-regulates aquaporin-4 expression in cultured astrocytes. J. Neurosci. Res. 2003, 72, 709-715. [CrossRef] [PubMed]

221. Lindsay, L.A.; Murphy, C.R. Aquaporin-1 increases in the rat myometrium during early pregnancy. J. Mol. Histol. 2004, 35, 75-79. [CrossRef] [PubMed]

222. Lindsay, L.A.; Murphy, C.R. Redistribution of aquaporins 1 and 5 in the rat uterus is dependent on progesterone: A study with light and electron microscopy. Reproduction 2006, 131, 369-378. [CrossRef] [PubMed]

223. He, R.H.; Sheng, J.Z.; Luo, Q.; Jin, F.; Wang, B.; Qian, Y.L.; Zhou, C.Y.; Sheng, X.; Huang, H.F. Aquaporin-2 expression in human endometrium correlates with serum ovarian steroid hormones. Life Sci. 2006, 79, 423-429. [CrossRef]

224. da Silva, I.V.; Santos, A.C.; Matos, A.; da Silva, A.P.; Soveral, G.; Rebelo, I.; Bicho, M. Association of Aquaporin-3, Aquaporin-7, NOS3 and CYBA polymorphisms with hypertensive disorders in women. Pregnancy Hypertens. 2021, 24, 44-49. [CrossRef]

225. Fasshauer, M.; Klein, J.; Lossner, U.; Klier, M.; Kralisch, S.; Paschke, R. Suppression of aquaporin adipose gene expression by isoproterenol, TNF $\alpha$, and dexamethasone. Horm. Metab. Res. 2003, 35, 222-227.

226. Prudente, S.; Flex, E.; Morini, E.; Turchi, F.; Capponi, D.; De Cosmo, S.E.A. A functional variant of the adipocyte glycerol channel aquaporin 7 gene is associated with obesity and related metabolic abnormalities. Diabetes 2007, 56, 1468-1474. [CrossRef]

227. O'Brien, J.; Hayder, H.; Zayed, Y.; Peng, C. Overview of microRNA biogenesis, mechanisms of actions, and circulation. Front. Endocrinol. 2018, 9, 402. [CrossRef]

228. Gharanei, S.; Shabir, K.; Brown, J.E.; Weickert, M.O.; Barber, T.M.; Kyrou, I.; Randeva, H.S. Regulatory microRNAs in Brown, Brite and White Adipose Tissue. Cells 2020, 9, 2489. [CrossRef] [PubMed] 
229. He, H.; Chen, K.; Wang, F.; Zhao, L.; Wan, X.; Wang, L.; Mo, Z. miR-204-5p promotes the adipogenic differentiation of human adipose-derived mesenchymal stem cells by modulating DVL3 expression and suppressing Wnt/ $\beta$-catenin signaling. Int. J. Mol. Med. 2015, 35, 1587-1595. [CrossRef] [PubMed]

230. Xu, Y.; Du, J.; Zhang, P.; Zhao, X.; Li, Q.; Jiang, A.; Jiang, D.; Tang, G.; Jiang, Y.; Wang, J.; et al. MicroRNA-125a-5p mediates 3T3-L1 preadipocyte proliferation and differentiation. Molecules 2018, 23, 317. [CrossRef] [PubMed]

231. Chen, C.; Peng, Y.; Peng, Y.; Peng, J.; Jiang, S. miR-135a-5p inhibits 3T3-L1 adipogenesis through activation of canonical Wnt/ $\beta$-catenin signaling. J. Mol. Endocrinol. 2014, 52, 311-320. [CrossRef]

232. Mori, M.A.; Thomou, T.; Boucher, J.; Lee, K.Y.; Lallukka, S.; Kim, J.K.; Torriani, M.; Yki-Järvinen, H.; Grinspoon, S.K.; Cypess, A.M.; et al. Altered miRNA processing disrupts brown/white adipocyte determination and associates with lipodystrophy. J. Clin. Investig. 2014, 124, 3339-3351. [CrossRef]

233. Engin, A.B. MicroRNA and adipogenesis. Obes. Lipotoxicity 2017, 960, 489-509.

234. Sun, T.; Fu, M.; Bookout, A.L.; Kliewer, S.A.; Mangelsdorf, D.J. MicroRNA let-7 regulates 3T3-L1 adipogenesis. Mol. Endocrinol. 2009, 23, 925-931. [CrossRef] [PubMed]

235. Xu, B.; Shen, J.; Li, D.; Ning, B.; Guo, L.; Bing, H.; Chen, J.; Li, Y. Overexpression of microRNA-9 inhibits 3T3-L1 cell adipogenesis by targeting PNPLA3 via activation of AMPK. Gene 2020, 730, 144260. [CrossRef]

236. Tian, L.; Song, Z.; Shao, W.; Du, W.W.; Zhao, L.R.; Zeng, K.; Yang, B.B.; Jin, T. Curcumin represses mouse 3T3-L1 cell adipogenic differentiation via inhibiting miR-17-5p and stimulating the Wnt signalling pathway effector Tcf7l2. Cell Death Dis. 2018, 8, e2559. [CrossRef]

237. An, X.; Ma, K.; Zhang, Z.; Zhao, T.; Zhang, X.; Tang, B.; Li, Z. miR-17, miR-21, and miR-143 enhance adipogenic differentiation from porcine bone marrow-derived mesenchymal stem cells. DNA Cell Biol. 2016, 35, 410-416. [CrossRef]

238. Lou, P.; Bi, X.; Tian, Y.; Li, G.; Kang, Q.; Lv, C.; Song, Y.; Xu, J.; Sheng, X.; Yang, X.; et al. MiR-22 modulates brown adipocyte thermogenesis by synergistically activating the glycolytic and mTORC1 signaling pathways. Theranostics 2021, 11, 3607. [CrossRef] [PubMed]

239. You, L.; Wang, Y.; Gao, Y.; Wang, X.; Cui, X.; Zhang, Y.; Pang, L.; Ji, C.; Guo, X.; Chi, X. The role of microRNA-23b-5p in regulating brown adipogenesis and thermogenic program. Endocr. Connect. 2020, 9, 457-470. [CrossRef] [PubMed]

240. Jin, M.; Wu, Y.; Wang, J.; Chen, J.; Huang, Y.; Rao, J.; Feng, C. MicroRNA-24 promotes 3T3-L1 adipocyte differentiation by directly targeting the MAPK7 signaling. Biochem. Biophys. Res. Commun. 2016, 474, 76-82. [CrossRef] [PubMed]

241. Acharya, A.; Berry, D.C.; Zhang, H.; Jiang, Y.; Jones, B.T.; Hammer, R.E.; Graff, J.M.; Mendell, J.T. miR-26 suppresses adipocyte progenitor differentiation and fat production by targeting Fbxl19. Genes Dev. 2019, 33, 1367-1380. [CrossRef] [PubMed]

242. Shi, C.; Huang, F.; Gu, X.; Zhang, M.; Wen, J.; Wang, X.; You, L.; Cui, X.; Ji, C.; Guo, X. Adipogenic miRNA and meta-signature miRNAs involved in human adipocyte differentiation and obesity. Oncotarget 2016, 7, 40830. [CrossRef] [PubMed]

243. Glantschnig, C.; Koenen, M.; Gil-Lozano, M.; Karbiener, M.; Pickrahn, I.; Williams-Dautovich, J.; Patel, R.; Cummins, C.L.; Giroud, M.; Hartleben, G.; et al. A miR-29a-driven negative feedback loop regulates peripheral glucocorticoid receptor signaling FASEB J. 2019, 33, 5924-5941. [CrossRef] [PubMed]

244. Zaragosi, L.E.; Wdziekonski, B.; Le Brigand, K.; Villageois, P.; Mari, B.; Waldmann, R.; Dani, C.; Barbry, P. Small RNA sequencing reveals miR-642a-3p as a novel adipocyte-specific microRNA and miR-30 as a key regulator of human adipogenesis. Genome Biol. 2011, 12, 1-13. [CrossRef] [PubMed]

245. Losko, M.; Lichawska-Cieslar, A.; Kulecka, M.; Paziewska, A.; Rumienczyk, I.; Mikula, M.; Jura, J. Ectopic overexpression of MCPIP1 impairs adipogenesis by modulating microRNAs. Biochim. Biophys. Acta BBA Mol. Cell Res. 2018, 1865, 186-195. [CrossRef]

246. Laine, S.K.; Alm, J.J.; Virtanen, S.P.; Aro, H.T.; Laitala-Leinonen, T.K. MicroRNAs miR-96, miR-124, and miR-199a regulate gene expression in human bone marrow-derived mesenchymal stem cells. J. Cell. Biochem. 2012, 113, 2687-2695. [CrossRef]

247. Zhang, W.; Yao, C.; Wei, Z.; Dong, Q. miR-128 promoted adipogenic differentiation and inhibited osteogenic differentiation of human mesenchymal stem cells by suppression of VEGF pathway. J. Recept. Signal Transduct. 2017, 37, 217-223. [CrossRef]

248. Fu, X.; Jin, L.; Han, L.; Yuan, Y.; Mu, Q.; Wang, H.; Yang, J.; Ning, G.; Zhou, D.; Zhang, Z. miR-129-5p inhibits adipogenesis through autophagy and may be a potential biomarker for obesity. Int. J. Endocrinol. 2019, 5069578, 1-11. [CrossRef] [PubMed]

249. Kim, S.; Park, J.W.; Lee, M.G.; Nam, K.H.; Park, J.H.; Oh, H.; Lee, J.; Han, J.; Yi, S.A.; Han, J.W. Reversine promotes browning of white adipocytes by suppressing miR-133a. J. Cell. Physiol. 2019, 234, 3800-3813. [CrossRef] [PubMed]

250. Zhang, P.; Du, J.; Wang, L.; Niu, L.; Zhao, Y.; Tang, G.; Jiang, Y.; Shuai, S.; Bai, L.; Li, X.; et al. MicroRNA-143a-3p modulates preadipocyte proliferation and differentiation by targeting MAPK7. Biomed. Pharmacother. 2018, 108, 531-539. [CrossRef] [PubMed]

251. Shen, L.; Li, Q.; Wang, J.; Zhao, Y.; Niu, L.; Bai, L.; Shuai, S.; Li, X.; Zhang, S.; Zhu, L. miR-144-3p promotes adipogenesis through releasing C/EBP $\alpha$ from Klf3 and CtBP2. Front. Genet. 2018, 9, 677. [CrossRef]

252. Xingyi, C.; Xinhao, M.; Raza, S.H.A.; Jianfang, W.; Xiaohui, W.; Chengcheng, L.; Xinran, Y.; Mei, C.; Zan, L. Bovine preadipocyte adipogenesis is regulated by bta-miR-150 through mTOR signalling. Front. Genet. 2021, 12, 6.

253. Dong, M.; Ye, Y.; Chen, Z.; Xiao, T.; Liu, W.; Hu, F. MicroRNA 182 is a Novel Negative Regulator of Adipogenesis by Targeting CCAAT/Enhancer-Binding Protein $\alpha$. Obesity 2020, 28, 1467-1476. [CrossRef] [PubMed]

254. Du, J.; Zhang, P.; Gan, M.; Zhao, X.; Xu, Y.; Li, Q.; Jiang, Y.; Tang, G.; Li, M.; Wang, J.; et al. MicroRNA-204-5p regulates 3T3-L1 preadipocyte proliferation, apoptosis and differentiation. Gene 2018, 668, 1-7. [CrossRef] 
255. Tang, R.; Ma, F.; Li, W.; Ouyang, S.; Liu, Z.; Wu, J. miR-206-3p inhibits 3T3-L1 cell adipogenesis via the c-Met/PI3K/Akt pathway. Int. J. Mol. Sci. 2017, 18, 1510. [CrossRef] [PubMed]

256. Ahonen, M.A.; Asghar, M.Y.; Parviainen, S.J.; Liebisch, G.; Höring, M.; Leidenius, M.; Fischer-Posovszky, P.; Wabitsch, M.; Mikkola, T.S.; Törnquist, K.; et al. Human adipocyte differentiation and composition of disease-relevant lipids are regulated by miR-221-3p. Biochim. Biophys. Acta BBA Mol. Cell Biol. Lipids 2021, 1866, 158841.

257. Wang, L.; Xu, L.; Xu, M.; Liu, G.; Xing, J.; Sun, C.; Ding, H. Obesity-associated MiR-342-3p promotes adipogenesis of mesenchymal stem cells by suppressing CtBP2 and releasing C/EBP $\alpha$ from CtBP2 binding. Cell. Physiol. Biochem. 2015, 35, 2285-2298. [CrossRef]

258. Ling, H.Y.; Wen, G.B.; Feng, S.D.; Tuo, Q.H.; Ou, H.S.; Yao, C.H.; Zhu, B.Y.; Gao, Z.P.; Zhang, L.; Liao, D.F. MicroRNA-375 promotes 3T3-L1 adipocyte differentiation through modulation of extracellular signal-regulated kinase signalling. Clin. Exp. Pharmacol. Physiol. 2011, 38, 239-246. [CrossRef] [PubMed]

259. Liu, S.Y.; Zhang, Y.Y.; Gao, Y.; Zhang, L.J.; Chen, H.Y.; Zhou, Q.; Chai, M.L.; Li, Q.Y.; Jiang, H.; Yuan, B.; et al. MiR-378 plays an important role in the differentiation of bovine preadipocytes. Cell. Physiol. Biochem. 2015, 36, 1552-1562. [CrossRef] [PubMed]

260. Di, W.; Amdanee, N.; Zhang, W.; Zhou, Y. Long-term exercise-secreted extracellular vesicles promote browning of white adipocytes by suppressing miR-191a-5p. Life Sci. 2020, 263, 118464. [CrossRef] [PubMed]

261. Zhang, Y.; Ma, Y.; Gu, M.; Peng, Y. IncRNA TUG1 promotes the brown remodeling of white adipose tissue by regulating miR-204-targeted SIRT1 in diabetic mice. Int. J. Mol. Med. 2020, 46, 2225-2234. [CrossRef]

262. Cai, Z.; Liu, J.; Bian, H.; Cai, J.; Guo, X. MiR-455 enhances adipogenic differentiation of 3T3-L1 cells through targeting uncoupling protein-1. Die Pharm. 2016, 71, 625-628.

263. Chen, Y.H.; Heneidi, S.; Lee, J.M.; Layman, L.C.; Stepp, D.W.; Gamboa, G.M.; Chen, B.S.; Chazenbalk, G.; Azziz, R. miRNA-93 inhibits GLUT4 and is overexpressed in adipose tissue of polycystic ovary syndrome patients and women with insulin resistance. Diabetes 2013, 62, 2278-2286. [CrossRef] [PubMed]

264. Bresciani, E.; Saletti, C.; Squillace, N.; Rizzi, L.; Molteni, L.; Meanti, R.; Omeljaniuk, R.J.; Biagini, G.; Gori, A.; Locatelli, V.; et al. miRNA-218 targets lipin-1 and glucose transporter type 4 genes in 3T3-L1 cells treated with lopinavir/ritonavir. Front. Pharmacol. 2019, 10, 461. [CrossRef]

265. Shi, Z.; Zhao, C.; Guo, X.; Ding, H.; Cui, Y.; Shen, R.; Liu, J. Differential expression of microRNAs in omental adipose tissue from gestational diabetes mellitus subjects reveals miR-222 as a regulator of ER $\alpha$ expression in estrogen-induced insulin resistance. Endocrinology 2014, 155, 1982-1990. [CrossRef]

266. Romero-Cordoba, S.L.; Rodriguez-Cuevas, S.; Bautista-Pina, V.; Maffuz-Aziz, A.; D’Ippolito, E.; Cosentino, G.; Baroni, S.; Iorio, M.V.; Hidalgo-Miranda, A. Loss of function of miR-342-3p results in MCT1 over-expression and contributes to oncogenic metabolic reprogramming in triple negative breast cancer. Sci. Rep. 2018, 8, 12252. [CrossRef]

267. Zheng, W.; Li, T.; Wei, J.; Zhang, Y.; Zuo, Q.; Lin, Y. Identification of miR-145 as a regulator of the cardiomyocyte inflammatory response and oxidative stress under hyperglycemia. Exp. Ther. Med. 2021, 21, 1-10. [CrossRef]

268. Hu, F.; Wang, M.; Xiao, T.; Yin, B.; He, L.; Meng, W.; Dong, M.; Liu, F. miR-30 promotes thermogenesis and the development of beige fat by targeting RIP140. Diabetes 2015, 64, 2056-2068. [CrossRef] [PubMed]

269. Wu, D.H.; Liang, H.; Lu, S.N.; Wang, H.; Su, Z.L.; Zhang, L.; Ma, J.Q.; Guo, M.; Tai, S.; Yu, S. miR-124 suppresses pancreatic ductal adenocarcinoma growth by regulating monocarboxylate transporter 1-mediated cancer lactate metabolism. Cell. Physiol. Biochem. 2018, 50, 924-935. [CrossRef]

270. Shaw, T.A.; Singaravelu, R.; Powdrill, M.H.; Nhan, J.; Ahmed, N.; Özcelik, D.; Pezacki, J.P. MicroRNA-124 regulates fatty acid and triglyceride homeostasis. Iscience 2018, 10, 149-157. [CrossRef] [PubMed]

271. Pan, S.; Cui, Y.; Fu, Z.; Zhang, L.; Xing, H. MicroRNA-128 is involved in dexamethasone-induced lipid accumulation via repressing SIRT1 expression in cultured pig preadipocytes. J. Steroid Biochem. Mol. Biol. 2019, 186, 185-195. [CrossRef] [PubMed]

272. Belarbi, Y.; Mejhert, N.; Lorente-Cebrián, S.; Dahlman, I.; Arner, P.; Rydén, M.; Kulyte, A. MicroRNA-193b controls adiponectin production in human white adipose tissue. J. Clin. Endocrinol. Metab. 2015, 100, E1084-E1088. [CrossRef]

273. Huang, Z.; Xu, A. Adipose Extracellular Vesicles in Intercellular and Inter-Organ Crosstalk in Metabolic Health and Diseases. Front. Immunol. 2021, 12, 463. [CrossRef]

274. Crewe, C.; Scherer, P.E. Intercellular and interorgan crosstalk through adipocyte extracellular vesicles. Rev. Endocr. Metab. Disord. 2021, 1-9. [CrossRef]

275. Huang, B.; Lu, J.; Ding, C.; Zou, Q.; Wang, W.; Li, H. Exosomes derived from human adipose mesenchymal stem cells improve ovary function of premature ovarian insufficiency by targeting SMAD. Stem Cell Res. Ther. 2018, 9, 1-12. [CrossRef]

276. Vienberg, S.; Geiger, J.; Madsen, S.; Dalgaard, L.T. Micro RNA s in metabolism. Acta Physiol. 2017, 219, 346-361. [CrossRef]

277. Catanzaro, G.; Filardi, T.; Sabato, C.; Vacca, A.; Migliaccio, S.; Morano, S.; Ferretti, E. Tissue and circulating microRNAs as biomarkers of response to obesity treatment strategies. J. Endocrinol. Investig. 2020, 1-16. [CrossRef]

278. López-Pastor, A.R.; Infante-Menéndez, J.; Escribano, Ó.; Gómez-Hernández, A. miRNA Dysregulation in the Development of Non-Alcoholic Fatty Liver Disease and the Related Disorders Type 2 Diabetes Mellitus and Cardiovascular Disease. Front. Med. 2020, 7. [CrossRef] [PubMed]

279. Mu, L.; Sun, X.; Tu, M.; Zhang, D. Non-coding RNAs in polycystic ovary syndrome: A systematic review and meta-analysis. Reprod. Biol. Endocrinol. 2021, 19, 1-18. [CrossRef] [PubMed]

280. Torres, J.L.; Novo-Veleiro, I.; Manzanedo, L.; Alvela-Suárez, L.; Macías, R.; Laso, F.J.; Marcos, M. Role of microRNAs in alcohol-induced liver disorders and non-alcoholic fatty liver disease. World J. Gastroenterol. 2018, 24, 4104. [CrossRef] [PubMed] 
281. Condorelli, G.; Latronico, M.V.; Cavarretta, E. microRNAs in cardiovascular diseases: Current knowledge and the road ahead. J. Am. Coll. Cardiol. 2014, 63, 2177-2187. [CrossRef] [PubMed]

282. Jusic, A.; Salgado-Somoza, A.; Paes, A.B.; Stefanizzi, F.M.; Martínez-Alarcón, N.; Pinet, F.; Martelli, F.; Devaux, Y.; Robinson, E.L.; Novella, S.; et al. Approaching sex differences in cardiovascular non-coding RNA research. Int. J. Mol. Sci. 2020, 21, 4890. [CrossRef] [PubMed]

283. Ghasemi, A.; Hashemy, S.I.; Azimi-Nezhad, M.; Dehghani, A.; Saeidi, J.; Mohtashami, M. The cross-talk between adipokines and miRNAs in health and obesity-mediated diseases. Clin. Chim. Acta 2019, 499, 41-53. [CrossRef] [PubMed]

284. Gomes, A.; Da Silva, I.V.; Rodrigues, C.M.; Castro, R.E.; Soveral, G. The emerging role of microRNAs in aquaporin regulation. Front. Chem. 2018, 6, 238. [CrossRef]

285. Wang, S.S.; Wu, L.J.; Xiao, H.B.; He, Y.; Yan, Y.X. A meta-analysis of dysregulated miRNAs in coronary heart disease. Life Sci. 2018, 215, 170-181. [CrossRef]

286. Calamita, G.; Perret, J.; Delporte, C. Aquaglyceroporins: Drug targets for metabolic diseases? Front. Physiol. 2018,9 , 851. [CrossRef] [PubMed]

287. Lee, D.H.; Park, D.B.; Lee, Y.K.; An, C.S.; Oh, Y.S.; Kang, J.S.; Kang, S.H.; Chung, M.Y. The effects of thiazolidinedione treatment on the regulations of aquaglyceroporins and glycerol kinase in OLETF rats. Metabolism 2005, 54, 1282-1289. [CrossRef]

288. Rena, G.; Hardie, D.G.; Pearson, E.R. The mechanisms of action of metformin. Diabetologia 2017, 60, 1577-1585. [CrossRef] [PubMed]

289. Facchinetti, F.; Unfer, V.; Dewailly, D.; Kamenov, Z.A.; Diamanti-Kandarakis, E.; Laganà, A.S.; Nestler, J.E.; Soulage, C.O. Inositols in polycystic ovary syndrome: An overview on the advances. Trends Endocrinol. Metab. 2020, 31, 435-447. [CrossRef] [PubMed]

290. Wawrzkiewicz-Jałowiecka, A.; Kowalczyk, K.; Trybek, P.; Jarosz, T.; Radosz, P.; Setlak, M.; Madej, P. In Search of New Therapeutics-Molecular Aspects of the PCOS Pathophysiology: Genetics, Hormones, Metabolism and Beyond. Int. J. Mol. Sci. 2020, 21, 7054. [CrossRef] [PubMed]

291. Condorelli, R.; La Vignera, S.; Mongiò̀, L.; Vitale, S.; Laganà, A.; Cimino, L.; Calogero, A. Myo-inositol as a male fertility molecule: Speed them up. Eur. Rev. Med. Pharmacol. Sci. 2017, 21, 30-35. [PubMed]

292. Pereira, R.; Sá, R.; Barros, A.; Sousa, M. Major regulatory mechanisms involved in sperm motility. Asian J. Androl. 2017, 19, 5. [CrossRef]

293. Facchinetti, F.; Espinola, M.S.B.; Dewailly, D.; Ozay, A.C.; Prapas, N.; Vazquez-Levin, M.; Wdowiak, A.; Unfer, V.; Appetecchia, M.; Aragona, C.; et al. Breakthroughs in the use of inositols for assisted reproductive treatment (ART). Trends Endocrinol. Metab. 2020, 31, 570-579. [CrossRef]

294. Zuo, M.; Liao, G.; Zhang, W.; Xu, D.; Lu, J.; Tang, M.; Yan, Y.; Hong, C.; Wang, Y. Effects of exogenous adiponectin supplementation in early pregnant PCOS mice on the metabolic syndrome of adult female offspring. J. Ovarian Res. 2021, 14, 1-12. [CrossRef]

295. Soveral, G.; Casini, A. Aquaporin modulators: A patent review (2010-2015). Expert Opin. Ther. Patents 2017, 27, 49-62. [CrossRef]

296. Beitz, E.; Golldack, A.; Rothert, M.; von Bülow, J. Challenges and achievements in the therapeutic modulation of aquaporin functionality. Pharmacol. Ther. 2015, 155, 22-35. [CrossRef]

297. Owona, B.A.; Abia, W.A.; Moundipa, P.F. Natural compounds flavonoids as modulators of inflammasomes in chronic diseases. Int. Immunopharmacol. 2020, 84, 106498. [CrossRef]

298. Pan, M.H.; Lai, C.S.; Ho, C.T. Anti-inflammatory activity of natural dietary flavonoids. Food Funct. 2010, 1, 15-31. [CrossRef] [PubMed]

299. Kicinska, A.; Kampa, R.P.; Daniluk, J.; Sek, A.; Jarmuszkiewicz, W.; Szewczyk, A.; Bednarczyk, P. Regulation of the mitochondrial BKCa channel by the citrus flavonoid naringenin as a potential means of preventing cell damage. Molecules 2020, $25,3010$. [CrossRef] [PubMed]

300. Lee, J.H.; Park, A.; Oh, K.J.; Lee, S.C.; Kim, W.K.; Bae, K.H. The role of adipose tissue mitochondria: Regulation of mitochondrial function for the treatment of metabolic diseases. Int. J. Mol. Sci. 2019, 20, 4924. [CrossRef] [PubMed]

301. Bastías-Pérez, M.; Zagmutt, S.; Soler-Vázquez, M.C.; Serra, D.; Mera, P.; Herrero, L. Impact of adaptive thermogenesis in mice on the treatment of obesity. Cells 2020, 9, 316. [CrossRef] [PubMed]

302. Fuller-Jackson, J.P.; Dordevic, A.L.; Clarke, I.J.; Henry, B.A. Effect of sex and sex steroids on brown adipose tissue heat production in humans. Eur. J. Endocrinol. 2020, 183, 343-355. [CrossRef] [PubMed]

303. de Morentin, P.B.M.; González-García, I.; Martins, L.; Lage, R.; Fernández-Mallo, D.; Martínez-Sánchez, N.; Ruíz-Pino, F.; Liu, J.; Morgan, D.A.; Pinilla, L.; et al. Estradiol regulates brown adipose tissue thermogenesis via hypothalamic AMPK. Cell Metab. 2014, 20, 41-53.

304. Shorakae, S.; Jona, E.; de Courten, B.; Lambert, G.W.; Lambert, E.A.; Phillips, S.E.; Clarke, I.J.; Teede, H.J.; Henry, B.A. Brown adipose tissue thermogenesis in polycystic ovary syndrome. Clin. Endocrinol. 2019, 90, 425-432. [CrossRef]

305. Lerner, A.; Kewada, D.; Ahmed, A.; Hardy, K.; Christian, M.; Franks, S. Androgen Reduces Mitochondrial Respiration in Mouse Brown Adipocytes: A Model for Disordered Energy Balance in Polycystic Ovary Syndrome. Int. J. Mol. Sci. 2021, $22,243$. [CrossRef]

306. Cohen, P. The hypogonadal-obesity cycle: Role of aromatase in modulating the testosterone-estradiol shunt-a major factor in the genesis of morbid obesity. Med. Hypotheses 1999, 52, 49-51. [CrossRef] 
307. Bellemare, V.; Laberge, P.; Noël, S.; Tchernof, A.; Luu-The, V. Differential estrogenic $17 \beta$-hydroxysteroid dehydrogenase activity and type $1217 \beta$-hydroxysteroid dehydrogenase expression levels in preadipocytes and differentiated adipocytes. J. Steroid Biochem. Mol. Biol. 2009, 114, 129-134. [CrossRef]

308. Wohlers, L.M.; Spangenburg, E.E. 17 $\beta$-estradiol supplementation attenuates ovariectomy-induced increases in ATGL signaling and reduced perilipin expression in visceral adipose tissue. J. Cell. Biochem. 2010, 110, 420-427. [CrossRef]

309. Dragano, N.; Milbank, E.; López, M. Estradiol and appetite: To eat or not to eat. Mol. Metab. 2020, 42, 101061. [CrossRef] [PubMed]

310. López, M.; Tena-Sempere, M. Estrogens and the control of energy homeostasis: A brain perspective. Trends Endocrinol. Metab. 2015, 26, 411-421. [CrossRef] [PubMed]

311. Kim, J.Y.; Jo, K.J.; Kim, O.S.; Kim, B.J.; Kang, D.W.; Lee, K.H.; Baik, H.W.; Han, M.S.; Lee, S.K. Parenteral 17beta-estradiol decreases fasting blood glucose levels in non-obese mice with short-term ovariectomy. Life Sci. 2010, 87, 358-366. [CrossRef]

312. Snyder, P.J.; Peachey, H.; Berlin, J.A.; Hannoush, P.; Haddad, G.; Dlewati, A.; Santanna, J.; Loh, L.; Lenrow, D.A.; Holmes, J.H.; et al. Effects of testosterone replacement in hypogonadal men. J. Clin. Endocrinol. Metab. 2000, 85, 2670-2677. [CrossRef]

313. Kalinchenko, S.Y.; Tishova, Y.A.; Mskhalaya, G.J.; Gooren, L.J.; Giltay, E.J.; Saad, F. Effects of testosterone supplementation on markers of the metabolic syndrome and inflammation in hypogonadal men with the metabolic syndrome: The double-blinded placebo-controlled Moscow study. Clin. Endocrinol. 2010, 73, 602-612. [CrossRef]

314. Bianchi, V.E. The anti-inflammatory effects of testosterone. J. Endocr. Soc. 2019, 3, 91-107. [CrossRef] [PubMed]

315. Muraleedharan, V.; Marsh, H.; Kapoor, D.; Channer, K.S.; Jones, T.H. Testosterone deficiency is associated with increased risk of mortality and testosterone replacement improves survival in men with type 2 diabetes. Eur. J. Endocrinol. 2013, 169, 725-733. [CrossRef] 